PNNL-10995

UC-810

Project Technical Information

RECEIVED

MAR 221996

OSTI

Summary of Rheological Studies

Related to HWVP Slurries

D.D. Lanning

P.A. Smith

G. Terrones

D.E. Larson

February 1996

Prepared for the U.S. Department of Energy under Contract DE-AC06-76RLO 1830

Pacific Northwest National Laboratory Operated for the U.S. Department of Energy by Battelle Memorial Institute 
PNNL-10995

UC- 810

Project Technical Information

\section{Summary of Rheological Studies Related to HWVP Slurries}

D. D. Lanning

P. A. Smith

G. Terrones

D. E. Larson

February 1996

Prepared for

the U.S. Department of Energy

under Contract DE-AC06-76RLO 1830

Pacific Northwest National Laboratory

Richland, Washington 99352

Reprnt of historical document PHTD-C93-03.02M. dated November 1993. Data, lormatting. and other conventions reffect standards at the original date of printing. Teclinscal peer rcviews and editorlal reviews may not have been performed. 


\title{
DISCLAIMER
}

This report was prepared as an account of work sponsored by an agency of the United States Government. Neither the United States Government nor any agency thereof, nor Battelle Memorial Institute, nor any of their employees, makes any warranty, express or implied, or assumes any legal liability or responsibility for the accuracy, completeness, or.usefulness of any information, apparatus, product, or process disclosed, or represents that its use would not infringe privately owned rights. Reference herein to any specific commercial product, process, or service by trade name, trademark, manufacturer, or otherwise does not necessarily constitute or imply its endorsement, recommendation, or favoring by the United States Government or any agency thereof, or Battelle Memorial Institute. The views and opinions of authors expressed herein do not necessarily state or reflect those of the United States Government or any agency thereof:

\author{
PACIFIC NORTHWEST NATIONAL LABORATORY \\ operated by \\ BATTELLE \\ for the \\ UNITED STATES DEPARTMENT OF ENERGY \\ under Contract DE-ACO6-76RLO 1830
}

\author{
Printed in the United States of America \\ Availabie to DOE and DOE contractors from the \\ Office of Scientific and Tectinical information, P.O. Box 62, Oak Ridge, TN 3783!; \\ prices available from (615) 576-8401.
}

Available to the public from the National Technical information Service, U.S. Department of Commerce, 5285 Port Royal Rd., Springfield, VA 22161 


\section{SUMMARY}

Numerous studies (Section 8) have addressed the rheological properties of simulated process slurries at the Savannah River Laboratory for the Defense Waste Processing Facility and at Pacific Northwest Laboratory (PNL) for the Hanford Waste Vitrification Plant (HWVP). These studies were reviewed to summarize existing data applicable to HWVP design. The reviewers determined that the existing data provide important information on the effects of feed variability, solids loading, temperature, formating, $\mathrm{pH}$, and scale-up. However, these data cannot serve as a basis for fundamental slurry transport calculations because data are not reported in sufficient detail over a range of shear rates and in appropriate terms to be sufficient for transport calculations. 
ACRONYMS

$\begin{array}{ll}\text { DUFF } & \text { Defense Waste Processing Facility } \\ \text { FNCAW } & \text { formated neutralized current acid waste } \\ \text { HWVP } & \text { Hanford Waste Vitrification Plant } \\ \text { MF } & \text { melter feed } \\ \text { NCAW } & \text { neutralized current acid waste } \\ \text { PAL } & \text { Pacific Northwest Laboratory } \\ \text { SHE } & \text { slurry mix evaporator } \\ \text { SMECT } & \text { slurry mix evaporator condensate tank } \\ \text { SR } & \text { Savannah River Laboratory } \\ \text { STAT } & \text { slurry receipt and adjustment tank } \\ \text { TO } & \text { total oxides } \\ \text { WO } & \text { waste oxides }\end{array}$

v 


\section{.}

.

. 


\section{CONTENTS}

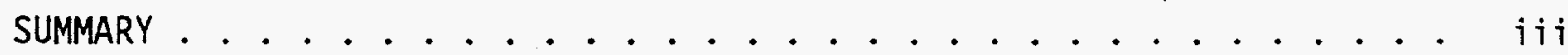

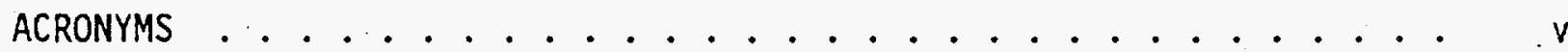

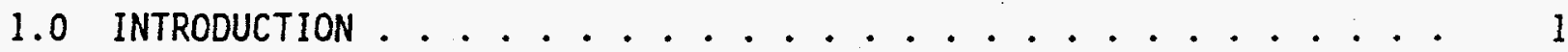

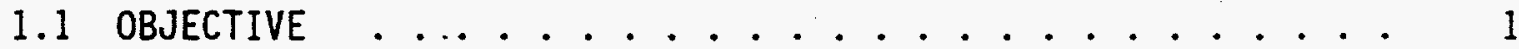

1.2 BACKGROUND . . . . . . . . . . . . . . . . 1

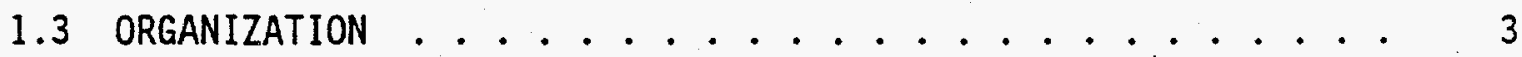

2.0 CONCLUSIONS AND RECOMMENDATIONS . . . . . . . . . . . . . 5

3.0 EXPERIMENTAL CONDITIONS . . . . . . . . . . . . . . . 7

4.0 RHEOLOGICAL MEASUREMENTS AND RESULTS . . . . . . . . . . . . 11

4.1 RESULTS FOR THE NCAW FEED SLURRIES . . . . . . . . . . . 12

4.2 RESULTS FOR MELTER, FEED SLURRIES . . . . . . . . . . . 15

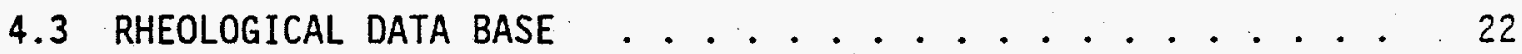

5.0 SYNOPSIS OF SOURCE-DOCUMENT CONCLUSIONS ON NCAW/MF
SLURRY RHEOLOGY . . . . . . . . . . . . . . . . . . . . . . . . 25

5.1 THORNTON 1987 . . . . . . . . . . . . . . . 25

5.2 FARNSWORTH ET AL. 1986 . . . . . . . . . . . . 25

5.3 FARNSWORTH 1987 . . . . . . . . . . . . . . 26

5.4 SCHEELE ET AL. 1985 . . . . . . . . . . . . . 27

5.5 WIEMERS 1990 . . . . . . . . . . . . . . 27

5.6 WIEMERS ET AL. 1987 . . . . . . . . . . . . 27

6.0 REFERENCES . . . . . . . . . . . . . . . . . . . . 29

7.0 CITED LETTER REPORTS . . . . . . . . . . . . . . . 31

8.0 ANNOTATED BIBLIOGRAPHY . . . . . . . . . . . . . . . . . 33

APPENDIX A - EFFECT OF STRAIN RATE ON VISCOSITY OF NCAW

AND MF SLURRIES ........................... A.l 


\section{FIGURES}

1 Sketch of Shear Stress Versus Strain Rate for a

Pseudo-plastic Material

2 Yield Stress Versus Concentration for NCAW . . . . . . . . . . 13

3 Apparent NCAW Viscosity as a Function of Oxide Concentration at a Shear Rate of $183 \mathrm{~s}^{-1} \ldots \ldots$. . . . . . . 13

4 Base-10 Logarithm of NCAW Yield Stress as a Function of Oxide Concentration ............... . . . 14

5 Log of NCAW Apparent Viscosity at $183 \mathrm{~s}^{-1}$ Shear Rate Versus Oxide Concentration . . . . . . . . . . . . . 14

6 Log of NCAW Viscosity Versus Shear Rate . . . . . . . . . 15

7 Effect of Formating on NCAW Yield Stress . . . . . . . . . . 16

8 Effect of Formating on NCAW Viscosity at Shear

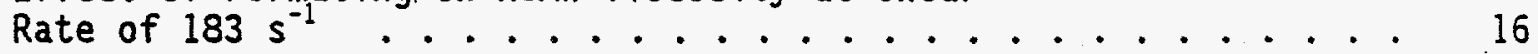

9 Log of NCAW Yield Stress Versus 0xide Concentration . . . . . . . 17

10 Log of NCAW Apparent Viscosity Versus Oxide Concentration ................... . . . 17

11 Log of NCAW Yield Stress Versus Oxide Concentration . . . . . 18

12 Log of NCAW Apparent Viscosity Versus 0xide Concentration at Shear Rate of $183 \mathrm{~s}^{-1}$............. 18

13 Yield Stress Versus Oxide Concentration for NCAW-to-MF Transition, Also Showing Formating Effects . . . . . 19

14 Apparent Viscosity Versus 0xide Concentration at Shear Rate of $183 \mathrm{~s}^{-1}$ for NCAW-to-MF Transition, Al so Showing Formating Effects . . . . . . . . . . . . . .

15 Log of Yield Stress Versus 0xide Concentration for MF Slurries ..................... . . . 20

16 Log of Apparent Viscosity Versus Oxide Concentration at a Shear Rate of $183 \mathrm{~s}^{-1}$ for MF Slurries . . . . . . . . . 
17 Log of Yield Stress Versus 0xide Concentration for MF Slurries . . 21

18 Log of Apparent Viscosity Versus Oxide Concentration for MF Slurries at a Shear Rate of $183 \mathrm{~s}^{-1} \ldots \ldots 21$

A.1 Log of NCAW Apparent Viscosity Versus 0xide Concentration at Three Shear Rates ..................

A.1

A.2 Log of MF Apparent Viscosity Versus Oxide Concentration at Three Shear Rates 


\section{TABLES}

1 Typical NCAW Composition ................ 8

2 Composition of Frit Material . . . . . . . . . . 8

3 Range of Major NCAW Components . . . . . . . . . . 9

4 Ranges of Physical Properties for Simulated HWVP NCAW . . . . . 9

5 Results and Comments. from Rheology Measurements ........ 10

6 Estimated Upper/Lower Bounds on Rheological Parameters for NCAW and MF .................. 23 


\subsection{INTRODUCTION}

\subsection{OBJECTIVE}

The objectives of this document are to 1) determine the applicability of existing rheological data to form constitutive equations for predicting fluid mechanical properties, 2) provide guidance to further refine rheological measurements for developing useful constitutive models, and 3) show the ranges of rheological conditions encountered in the previous studies. The rheological properties of Hanford Waste Vitrification Plant (HWVP) feed slurry have not yet been comprehensively characterized. Therefore, a "form, fit, and function" connection has yet to be developed between slurry rheology and HWVP equipment and piping. However, simulated feed slurries have been rheologically measured during various scoping studies (Thornton 1987; Scheele et al. 1985; Farnsworth 1987; Farnsworth et a7. 1986; Wiemers et a1. 1987; Wiemers $1990 ;),{ }^{(a)}$ and these measurements form a data base. Whether the data base is sufficient to form the basis of HWVP design depends on an acceptable degree of overdesign and operating flexibility inherent in the HWVP design, and on the characteristics of actual feed slurries compared to the simulated slurries studied to date.

This letter report satisfies contractor milestone, PHTD C93-03.02M as described in the FY 1993 Pacific Northwest Laboratory Hanford Waste Plant Technology Development (PHTD) Project Work Plan. ${ }^{(b)}$

\subsection{BACKGROUND}

Numerous studies (see Section 8) have addressed the rheological properties of simulated process slurries developed at Savannah River Laboratory (SRL) for the Defenșe Waste Processing Facility (DWPF) and at Pacific Northwest Laboratory (PNL) for the HWVP. These studies were reviewed by the

(a) The following works are not publically available: Thornton 1987, Scheele et a1. 1985, Farnsworth 1987, Wiemers et al. 1987, Wiemers 1990, and Hamm 1984. See complete 1 ist in Section 7.

(b) FY 1993 Pacific Northwest Laboratory Hanford Waste Plant Technology Development, Project Work Plan. Draft. December 1992. PHTD-93-002Rev. 0. 
authors to summarize the data applicable for HWVP design. Based on several exploratory rheological characterizations carried out at PNL (Scheele et a1. 1985; Farnsworth et al. 1986; Thornton 1987; Farnsworth 1987), it was concluded that the rheological properties of the HWVP and those of the DWPF feeds are different. The use of rheological data for a material that does not match the composition of the HWVP is not advisable. In addition, the rheological measurements taken at SRL for the DWPF cannot be generalized to construct general constitutive model equations. The constitutive equations would describe slurry flow for all anticipated conditions. Simply, the full range of data required to develop these equations does not exist.

Investigators at SRL reduced DWPF rheological data to fit the Bingham plastic model. Bingham plastic behavior was assumed a priori, for some slurries. Hamm (1984) showed substantial scatter for the correlation of viscosity and weight percent solids. It has been known for several years that not all HWVP slurries behave like Bingham plastics. In general, Farnsworth et al. (1986) showed the HWVP slurry rheology can be described:

$$
\tau=\tau_{0}+\eta \dot{\gamma}^{n}
$$

where $\tau$ is the shear stress, $\tau_{0}$ is the yield stress, $\eta$ is the viscosity, $\dot{\gamma}$ is the shear strain rate, $n=1$ for a Bingham plastic, $n<1$ for yield pseudoplastic, and is $n>1$ for yield dilatant.

Because the DWPF and HWV slurries behave differently, the rheological characterization of DWPF slurries is of limited value for constructing constitutive equations applicable to HWVP. A similar conclusion was previously reached by PNL investigators, "Designing simulated HWVP feeds to DWPF design criteria is not meaningful due to the more yield pseudoplastic nature of the HWVP material," (Farnsworth et al. 1986). This report focuses on rheological studies directly related to HWVP slurries carried out at PNL.

The previous rheological studies at SRL and PNL did not attempt to obtain a rheological model for a particular transport application. Rather, those studies focused on identifying general trends of rheological behavior when the slurries were subjected to conditions such as formic acid addition, 
glass-forming frit addition, and boiling. In most cases, the rheological characterization was reported as yield stress and apparent viscosities (see Appendix A) at only three arbitrarily chosen strain rate values. The data can be used to establish boundary conditions for slurry transport but are not sufficient for the development of a constitutive equation. However, it is not clear that a constitutive equation is required.

\subsection{ORGANIZATION}

In this document, conclusions and recommendations are presented in Section 2. The physical characteristics of the studied slurries are described in Section 3, Section 4 presents the rheological measurements and results, and Section 5 contains a synopsis of source document conclusions. Sections 6,7 , and 8 present references, cited letter reports, and an annotated bibliography, respectively. 


\subsection{CONCLUSIONS AND RECOMMENDATIONS}

Based on available data review, the following conclusions were drawn:

- The existing data relevant to rheology provide important information regarding effects of feed variability, solids loading, temperature, formating, $\mathrm{pH}$, and scale-up.

- The existing data cannot serve as a basis for fundamental transport calculations. Hence, constitutive equations cannot be developed from this data. It is not clear that constitutive equations are required. The data can be used to define bounding conditions for which representative experimental data have been obtained. These bounding conditions may be useful if an engineering approach is taken for slurry transport.

- The absence of a fundamental data base resulted from a lack of emphasis on rheology. The existing data base resulted largely from investigations focused on other aspects of the HWVP. The rheology measurements were taken as part of the work but were not considered in-depth.

The following recommendation is made:

- Future experiments must meet the informational requirements of transport calculations. 



\subsection{EXPERIMENTAL CONDITIONS}

The slurries for which rheological measurements have been taken fall into two categories: 1) HWVP feed material that simulates neutralized current acid waste (NCAW), and 2) NCAW to which glass-forming frit was added, which was then designated as melter feed (MF). Typically (pre 1988), the simulated NCAW feed materials are produced by slurrying metal hydroxides, sulfates, fluorides, and nitrates in water. Post 1988 slurries were made by precipitation of hydroxides from nitrate solutions for major (see below) components while the minor components were added as hydroxides, oxides, sulfates, phosphates, fluorides, chlorides, and nitrates. The equivalent total metal oxide concentrations typically range from 50 to $250 \mathrm{~g}$ of waste oxides (WO) per liter. The frit addition raises the total oxide (TO) concentration to 400 to $600 \mathrm{~g} / \mathrm{L}$. Particle sizes in the NCAW slurries are typically $<10 \mu$, whereas the frit particles range from 74 to $177 \mu$.

Typical NCAW and frit compositions are given in Tables 1 and 2, respectiveTy. The major constituents of the NCAW are iron, aluminum, sodium, and zirconium. Deliberate composition variations were produced and tested as reported in Farnsworth (1987) (e.g., high/low iron, high/low aluminum, high/ low sodium, and high zirconium). The ranges of these variations are summarized in Table 3.

The chemical characteristics of the NCAW are modified by adding formic acid, a process referred to as formating. Formating reduces the $\mathrm{pH}$ of the simulated waste from significantly basic ( $\mathrm{pH} 10$ to 11) to neutral or acidic (pH 7 to 4). The ranges of slurry concentration, density, and $\mathrm{pH}$ from the various references are summarized in Table 4.

A summary of the rheological results and comments from each referenced study are given in Table 5. As can be seen, a wide range of results were obtained at comparable ranges of concentration. These results are amplified and compared more fully in the following subsection. 
TABLE 1. Typical NCAW Composition (Wiemers 1990)

$\begin{array}{crr}\text { Element } & & \begin{array}{r}\text { Content } \\ (\mathrm{g} / \mathrm{L})\end{array} \\ \mathrm{Al} & & 7.42 \\ \mathrm{~B} & & 0.05 \\ \mathrm{Ba} & 0.56 \\ \mathrm{Ca} & 0.33 \\ \mathrm{Cd} & 3.64 \\ \mathrm{Ce} & 0.76 \\ \mathrm{Cr} & 0.53 \\ \mathrm{Cu} & 0.74 \\ \mathrm{Fe} & 30.52 \\ \mathrm{La} & 3.85 \\ \mathrm{Mg} & 0.34 \\ \mathrm{Mn} & 0.59 \\ \mathrm{Mo} & 1.25 \\ \mathrm{Na} & 20.81 \\ \mathrm{Nd} & 4.81 \\ \mathrm{Ni} & 2.82 \\ \mathrm{Ru} & 0.75 \\ \mathrm{SO} & 1.02 \\ \mathrm{Si} & 2.92 \\ \mathrm{Sr} & 0.53 \\ \mathrm{Y} & 0.25 \\ \mathrm{Zr} & 17.31 \\ \text { TOTAL } & 101.80\end{array}$

TABLE 2. Composition of Frit Material (Farnsworth et al. 1986)

Oxide

$\mathrm{SiO}_{2}$

$\mathrm{Na}_{2} \mathrm{O}$

$\mathrm{Li}_{2}^{2} \mathrm{O}$

$\mathrm{CaO}$

MgO
Content

(wt\%)

67.3

12.7

10.3

5.0

3.7

1.0 
TABLE 3. Range of Major NCAW Components

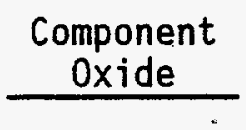

$$
\begin{aligned}
& \mathrm{Fe}_{2} \mathrm{O}_{3} \\
& \mathrm{Al}_{2} \mathrm{O}_{3} \\
& \mathrm{Na}_{2} \mathrm{O} \\
& \mathrm{ZrO} \mathrm{O}_{2}
\end{aligned}
$$

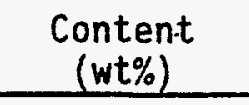

12.0 to 66.0

1.6 to 26.0

\begin{tabular}{|c|c|c|c|c|c|}
\hline Reference & $\begin{array}{l}\text { Composition } \\
\left(\text { wt\% } \mathrm{Fe}_{2} \mathrm{O}_{3}\right)\end{array}$ & $\begin{array}{c}\text { Concentration } \\
(\mathrm{g} \mathrm{TO} / \mathrm{L}) \\
\end{array}$ & $\mathrm{pH}$ & $\begin{array}{c}\text { Density } \\
(\mathrm{g} / \mathrm{mL})\end{array}$ & $\begin{array}{c}\text { Suspended } \\
\text { Solids } \\
\text { (wt\%) } \\
\end{array}$ \\
\hline $\begin{array}{l}\text { Thornton } \\
1987\end{array}$ & $\begin{array}{l}\text { HWS\& (44) } \\
\text { HWS9 (29) }\end{array}$ & 50 to 427 & 4 to 12 & 1.03 to 1.42 & 4 to 30 \\
\hline $\begin{array}{l}\text { Scheele } \\
1985\end{array}$ & $\operatorname{MWSG}^{\operatorname{Ha}}(41)$ & $\begin{array}{l}17 \text { to } 150 \\
400 \text { to } 500\end{array}$ & $\begin{array}{l}4 \text { to } 9 \\
6 \text { to } 7\end{array}$ & $\begin{array}{l}1.04 \text { to } 1.13 \\
1.2 \text { to } 1.3\end{array}$ & $\begin{array}{l}1.6 \text { to } 17 \\
11 \text { to } 40\end{array}$ \\
\hline $\begin{array}{l}\text { Farnsworth } \\
1987\end{array}$ & $\begin{array}{l}\text { NCAW84 (12 } \\
\text { to } 60)\end{array}$ & 140 & 3 to 12 & $N A^{(b)}$ & NA \\
\hline $\begin{array}{l}\text { Farnsworth } \\
1986\end{array}$ & $\begin{array}{l}\text { NA }(40) \\
\text { MF }\end{array}$ & $\begin{array}{l}50 \text { to } 275 \\
450 \text { to } 600\end{array}$ & $\begin{array}{l}4 \text { to } 12 \\
6 \text { to } 7\end{array}$ & $\begin{array}{l}1.04 \text { to } 1.2 \\
1.3 \text { to } 1.4\end{array}$ & $\begin{array}{l}4 \text { to } 17 \\
35 \text { to } 43\end{array}$ \\
\hline $\begin{array}{l}\text { Wiemers } \\
1990\end{array}$ & NA (29) & 125,150 & 7 to 9 & 1.08 to 1.12 & $15.4-17.5$ \\
\hline $\begin{array}{l}\text { Wiemers } \\
1987\end{array}$ & HWS11(28) & 144 & $\begin{array}{l}4.3 \text { to } \\
5.4\end{array}$ & 1.10 to 1.13 & NA \\
\hline
\end{tabular}

4.5 to 22.0

0.0 to 40.0

TABLE 4. Ranges of Physical Properties for Simulated HWVP NCAW

(a) Melter feed.

(b) Not available. 


\section{TABLE 5. Results and Comments from Rheology Measurements}

\begin{tabular}{|c|c|c|c|c|}
\hline \multirow[b]{2}{*}{ Reference } & \multicolumn{3}{|c|}{ Rheology Results } & \multirow[b]{2}{*}{ Comments } \\
\hline & $\begin{array}{c}\text { Material and } \\
\text { Concentration, } \\
\mathrm{g} \mathrm{WO/L}\end{array}$ & $\begin{array}{c}\text { Yield } \\
\text { Stress } \\
\text { dyne } / \mathrm{cm}^{2}\end{array}$ & $\begin{array}{c}\text { Viscosity, } \\
C p\end{array}$ & \\
\hline . & & • & & $\begin{array}{l}\text { Note: Viscosity Data reported } \\
\text { at } 183.323 \text { and } 468 \mathrm{~s}^{-1} \text { unless } \\
\text { otherwise noted. Data taken at } \\
\text { room temperature (RT) unless } \\
\text { otherwise noted. }\end{array}$ \\
\hline Thornton 1987 & NCAW, 50 to 426 & 0.5 to 406 & 3 to 300 & $\begin{array}{l}\text { Two simulated slurries (HWS9 } \\
\text { and HWS7) are compared over a } \\
\text { broad range of concentrations. } \\
\text { Slurries below } 150 \mathrm{~g} \text { wO/L are } \\
\text { unformated. those above are } \\
\text { formated to pH } 4 \text { : both types } \\
\text { tested at } 150 \mathrm{~g} \text { WO/L. }\end{array}$ \\
\hline Scheele et al. 1985 & $\begin{array}{l}\text { NCAW, } 17-150 \\
\text { MF, } 400 \text { and } 500\end{array}$ & $\begin{array}{l}\text { NCAW, 2-43 } \\
M F, 5-20 \\
\text { (room tem- } \\
\text { perature) }\end{array}$ & $\begin{array}{l}\text { NCAW, 3-34 } \\
\text { MF, 7-20 } \\
\text { (room tem- } \\
\text { perature) }\end{array}$ & $\begin{array}{l}\text { Oniy one composition and a faw } \\
\text { concentrations are actually } \\
\text { represented }(17,100,125,150 \mathrm{~g} / \mathrm{L} \\
\text { of wO for NCAW, } 400 \text { and } 500 \text { for } \\
\text { MF). The viscosity, is only } \\
\text { reported at } 183 \mathrm{~s} \text {. Several } \\
\text { levels of formating are tested. } \\
\text { and tests were conducted at } \\
\text { three temperature levels } \\
\left(25,50,95^{\circ} \mathrm{C}\right) \text {. with inconclu- } \\
\text { sive results on temperature } \\
\text { dependence. }\end{array}$ \\
\hline Farnsworth 1987 & NCAW, 150 & $\begin{array}{l}2-120 \\
(2-30, \text { for } \\
\text { standard-mix } \\
\text { FNCAW) }\end{array}$ & $\begin{array}{l}3-100 \\
(10-30, \text { for } \\
\text { standard-mix } \\
\text { FNCAW })\end{array}$ & $\begin{array}{l}\text { Nine compositions were tested } \\
\text { at a fixed concentration } \\
\text { (nominally } 150 \mathrm{~g} / \mathrm{L} \text { ). represent- } \\
\text { ing extremes in content for the } \\
\text { major constituents. Varying } \\
\text { levels of formating were } \\
\text { tested, taking the pH from } 12 \\
\text { down to } 4 \text {. Viscosity determined } \\
\text { at } 201,302 \text {, and } 453 \mathrm{~s} 1 \text {. Con- } \\
\text { sistency values reported. }\end{array}$ \\
\hline Farnsworth et al. 1986 & $\begin{array}{l}\text { NCAW, 50-250 } \\
\text { MF, } 450-600\end{array}$ & $\begin{array}{l}\text { NCAW. } 1-400 \\
\text { MF. } 30-250\end{array}$ & $\begin{array}{l}\text { NCAW, 5-300 } \\
\text { MF, 15-150 }\end{array}$ & $\begin{array}{l}\text { One composition represented. } \\
\text { Variations in agitation level. } \\
\text { aging. and formating also } \\
\text { tested. }\end{array}$ \\
\hline Wiemers 1990 & NCAW, 125 and 150 & $5-21$ & $\begin{array}{r}5-18 \\
-\end{array}$ & $\begin{array}{l}\text { Basically one composition and } \\
\text { one concentration were tested. } \\
\text { with variations in carbonate } \\
\text { content and formating. }\end{array}$ \\
\hline Wiemers et al. 1987 & NCAW, 144 & $100-150$ & $40-110$ & $\begin{array}{l}\text { One composition and one con- } \\
\text { centration were tested, with } \\
\text { variation in formating. The } \\
\text { unusually high results were } \\
\text { attributed to gelling of the } \\
\text { ferric hydroxide solution. }\end{array}$ \\
\hline
\end{tabular}




\subsection{RHEOLOGICAL MEASUREMENTS AND RESULTS}

The raw rheological data base consists of a collection of rheograms, which are strip-chart recordings of the torque and speed of a Haake concentric cylinder viscometer. Using standardized equations and Haake instrument procedures, the torque and speed data were reduced to shear stress and shear strain rate data, from which yield stress and apparent viscosity can be deduced. The apparent viscosity is the ratio of shear stress to strain rate at a particular strain rate. Most of these investigations were performed without the aid of data fitting routines that are currently available with viscometers. However, Wiemers et a1. (1987) and Wiemers (1990) did fit the power law using a statistical approach. The yield stress is defined as the point on the stress-strain curve where the slurry appears to transition from an elastic solid to a viscous liquid (see Figure 1).

The apparent viscosities were recorded and tabulated at three shear strain rate levels: 183,383 , and $468 \mathrm{~s}^{-1}$ (Farnsworth [1987] only, the shear

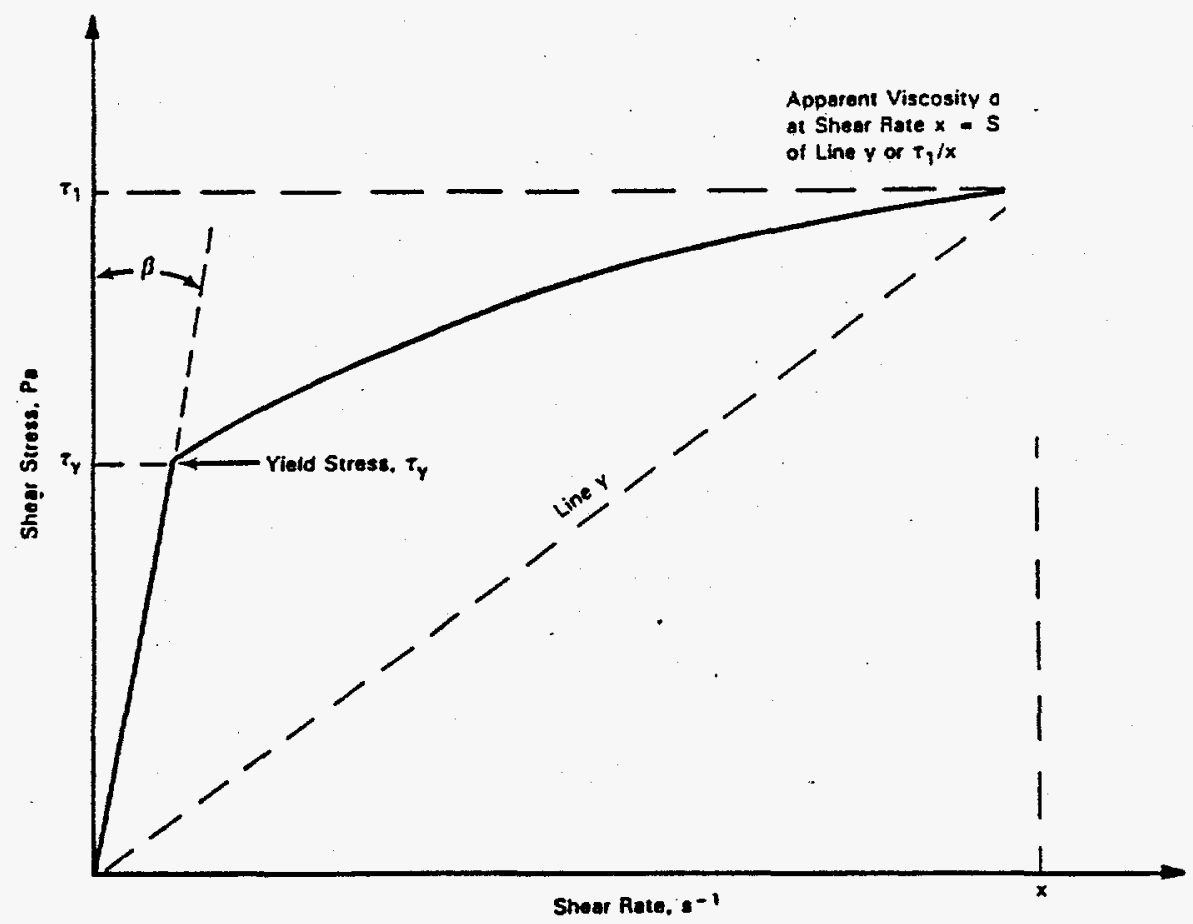

FIGURE 1. Sketch of Shear Stress Versus Strain Rate for a Pseudo-plastic Material 
strain rates are 201,302 , and $453 \mathrm{~s}^{-1}$ ). All measurements were conducted at controlled near-room temperature $\left(25^{\circ} \mathrm{C}\right)$, unless otherwise noted. The primary. parameters that were deliberately varied in the rheological measurements were composition, concentration, and the degree of formating of the slurries.

\subsection{RESULTS FOR THE NCAW FEED SLURRIES}

Over the total concentration range studied for the simulated NCAW, oxide concentration itself was the dominant determinant of yield stress and viscosity. Both the yield stress and apparent viscosity were exponential functions of the concentration, as demonstrated in Figures 2 and 3 , for typical data taken from Thornton (1987). The variation is consistently exponential, as demonstrated in Figures 4 and 5, where logarithms of yield stress and apparent viscosity, respectively, are plotted versus the oxide concentration for the formated $(\mathrm{pH}=-4)$ samples. The straight-line behavior of this plot indicates a purely exponential function.

The viscosity within a given data set consistently decreases with increasing strain rate, which is typical of shear thinning slurries. However, for the range of strain rates that were studied, the effect of rate is secondary to concentration. This relationship is demonstrated in Figure 6 , where the data from Thornton (1987) at all three strain rates are plotted versus concentration.

Formating was introduced to control foaming characteristics in the melter. Additionally, formating reduces the yield stress and the apparent viscosity of the feed slurry (see Figures 7 and 8 [Farnsworth et a1. 1986]). Thus, when evaluating existing rheological data from the various references, it is important whether or not the data were taken from slurries that were comparably formated. The $\mathrm{pH}$ values can be taken as an indicator of the feed reactions and the amount of formic acid added.

Different preparation procedures apparently affect the resulting viscosities and yield stresses. These effects are demonstrated by comparing Figures 4 and 5 (taken from Thornton [1987] for Batch HWS9) with Figures 9 nd 10 (taken from Farnsworth et a]. [1986]); these extreme variations generally bound the rheological results taken from the other references. In Figures 11 


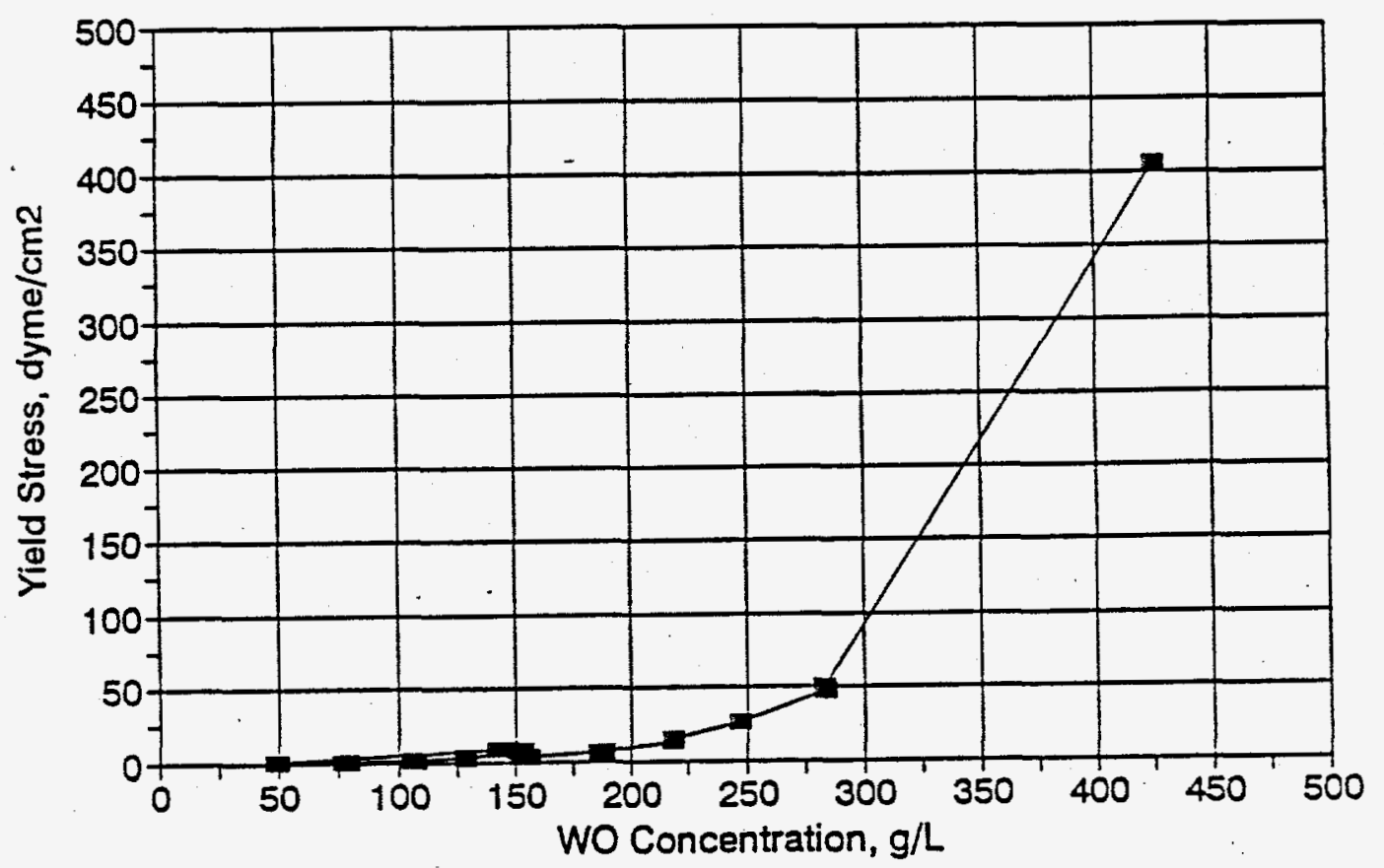

FIGURE 2. Yield Stress Versus Concentration for NCAW (Thornton 1987)

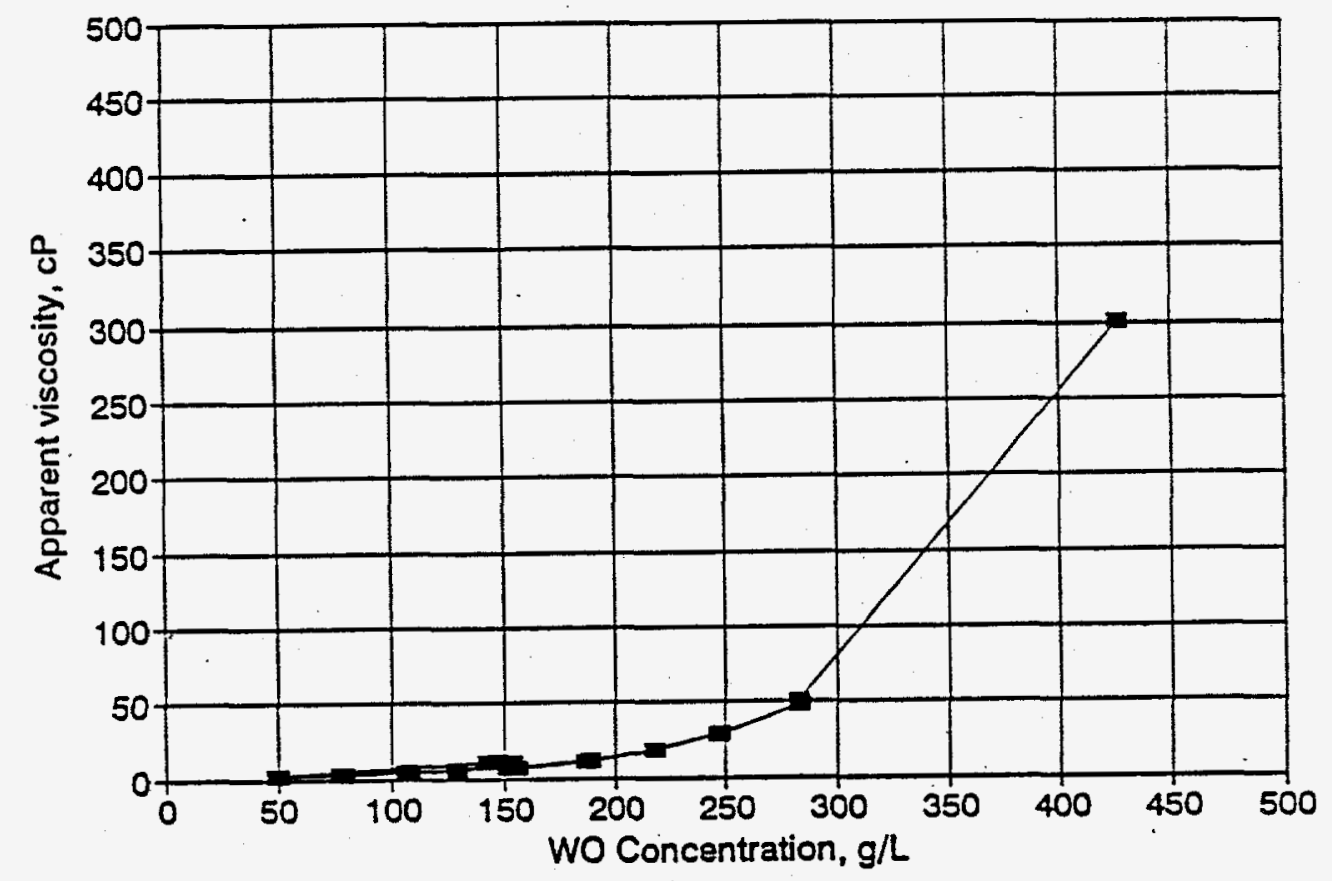

FIGURE 3. Apparent NCAW Viscosity as a Function of 0xide Concentration at a Shear Rate of $183 \mathrm{~s}^{-1}$ (Thornton 1987) 


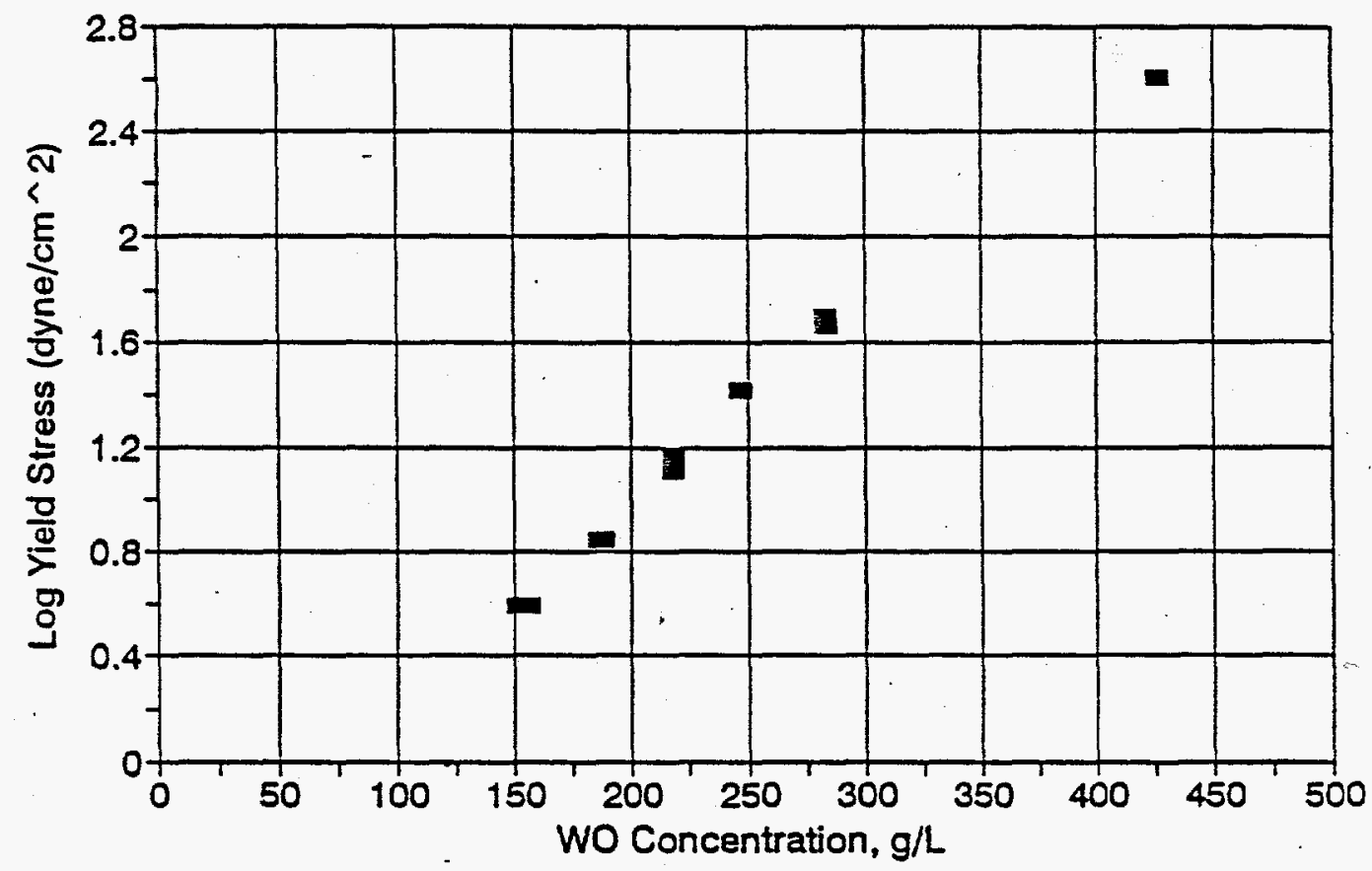

FIGURE 4. Base-10 Logarithm of NCAW Yield Stress as a Function of Oxide Concentration (Thornton 1987, formated data only)

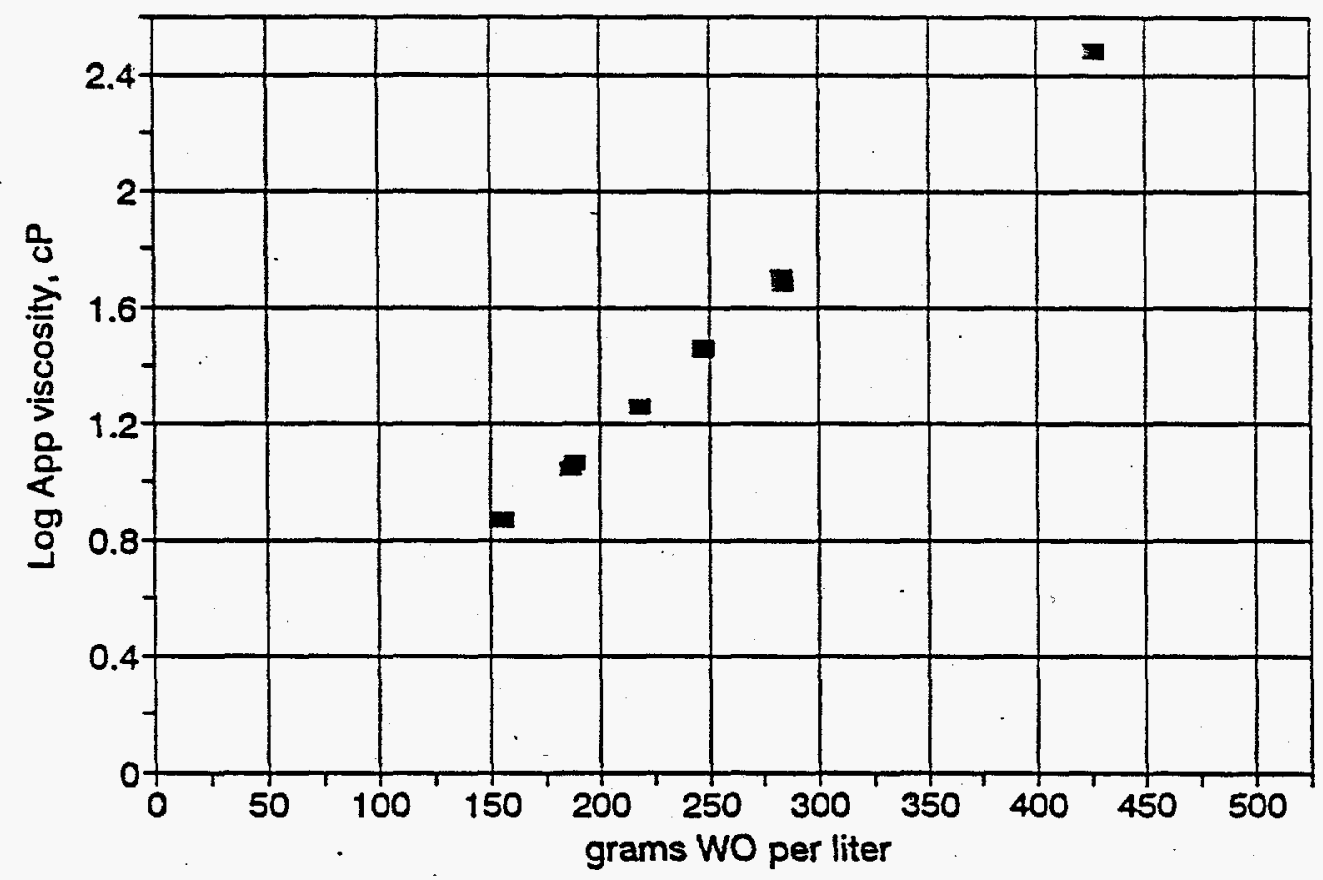

FIGURE 5. Log of NCAW Apparent Viscosity at $183 \mathrm{~s}^{-1}$ Shear Rate Versus 0xide Concentration (Thornton 1987, formated data only) 

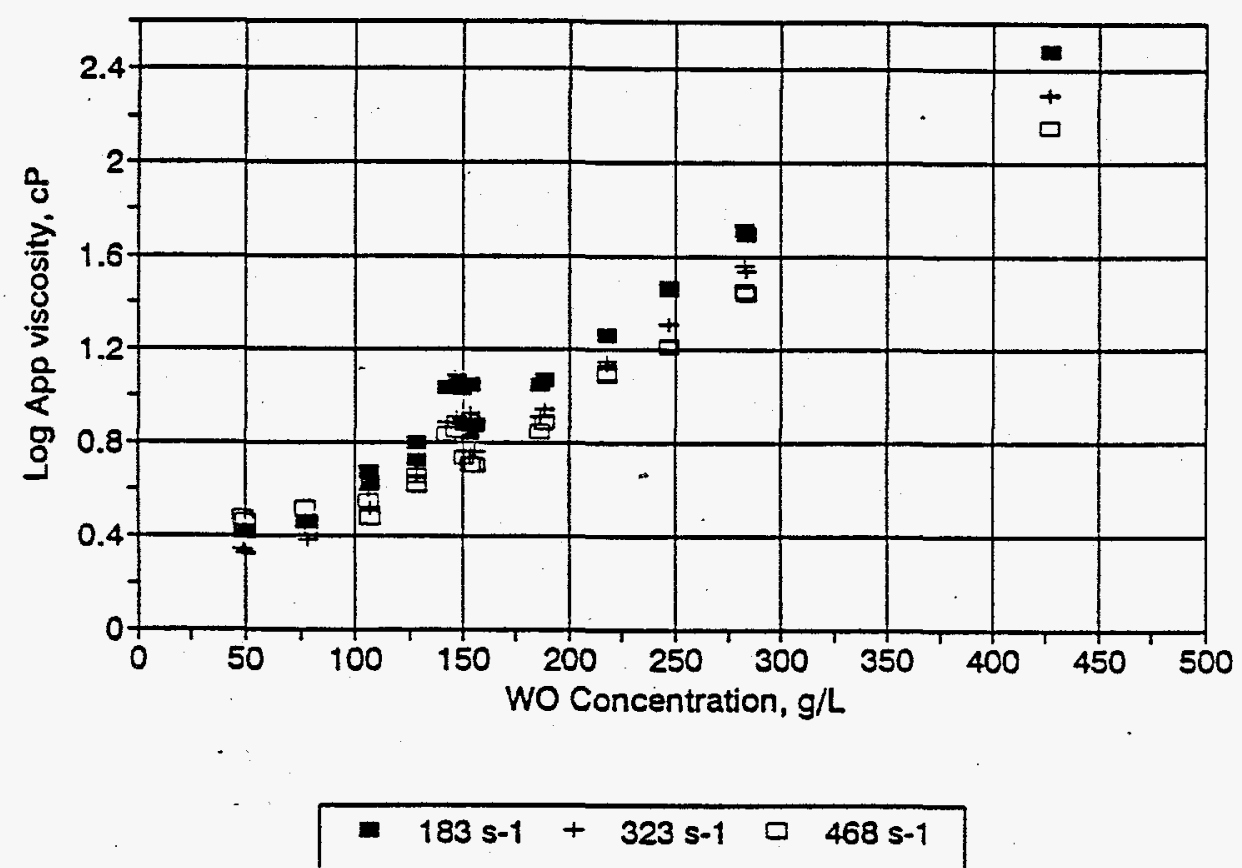

FIGURE 6. Log of NCAW Viscosity Versus Shear Rate (from Thornton 1987, al1. three shear rates)

and 12, the yield stresses and apparent viscosities (at $183 \mathrm{~s}^{-1}$ ) are shown for the formated samples from all references except Farnsworth et a7. (1986). The Wiemers et a1. (1987) results are extremely high and appear to be related to an unusual gelling of the iron hydroxide solution used in sample preparation. These plots, together with the companion plots at the higher strain rates (Appendix A), represent the current best estimates of the trends and bounds of the rheological parameters for the HWVP feed slurries.

\subsection{RESULTS FOR MELTER FEED SLURRIES}

Adding frit to the feed slurries to form MF slurries decreases the yield stress and apparent viscosity, as illustrated by Figures 13 and 14 (Farnsworth et a1. 1986). Within the MF concentration range (400 to $600 \mathrm{~g} \mathrm{TO} / \mathrm{L}$ ), the yield stress and viscosity are exponentially dependent on concentration (Figure 15 and 16). The MF rheological parameters seem less sensitive to variations in feed preparation and composition (Figures 17 and 18), probably because MF rheology is dominated by the properties of the frit. Figures 17 


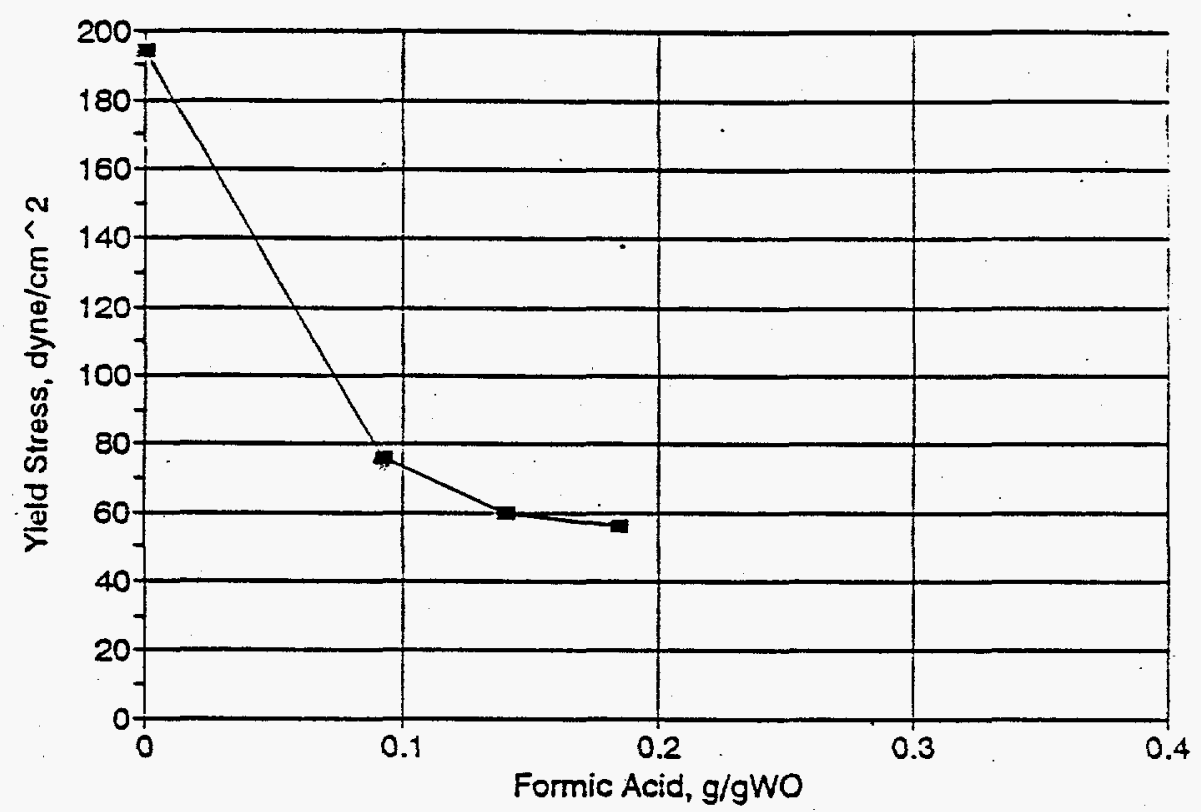

FIGURE 7. Effect of Formating on NCAW Yield Stress (Farnsworth et al. 1986)

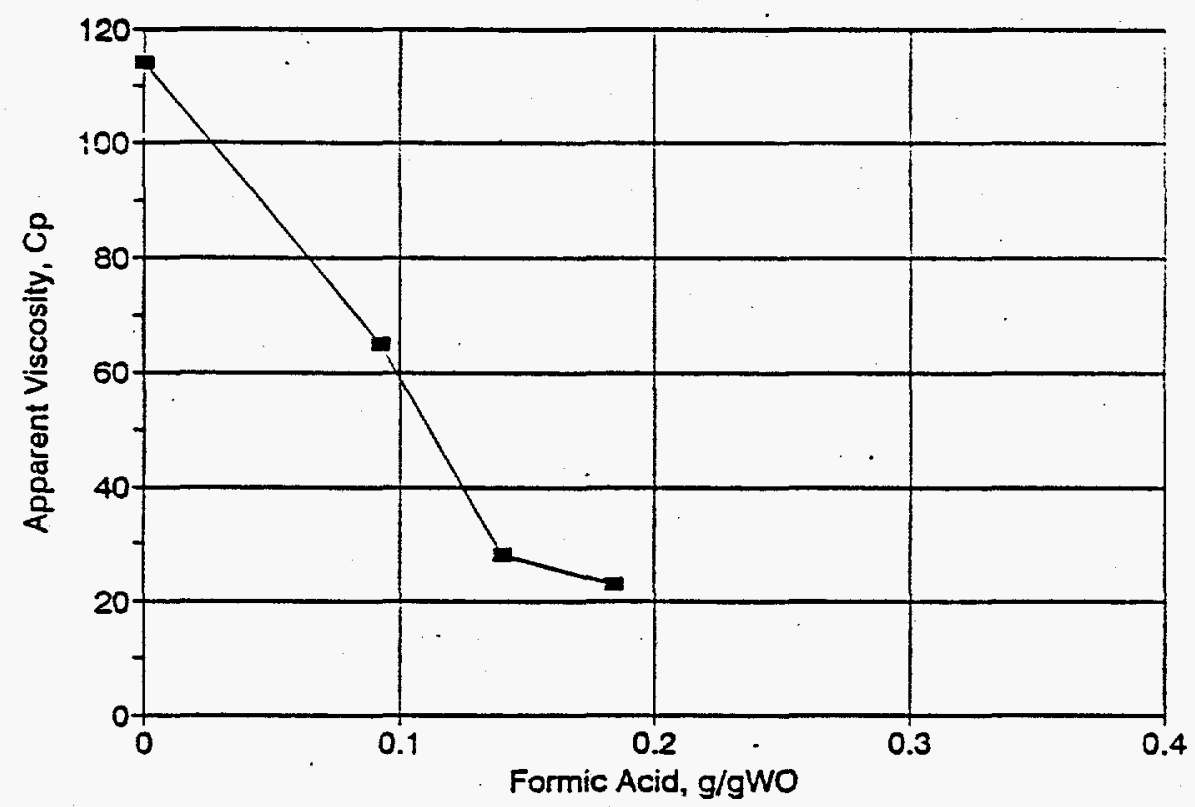

FIGURE 8. Effect of Formating on NCAW Viscosity at Shear Rate of $183 \mathrm{~s}^{-1}$ (Farnsworth et a1. 1986) 


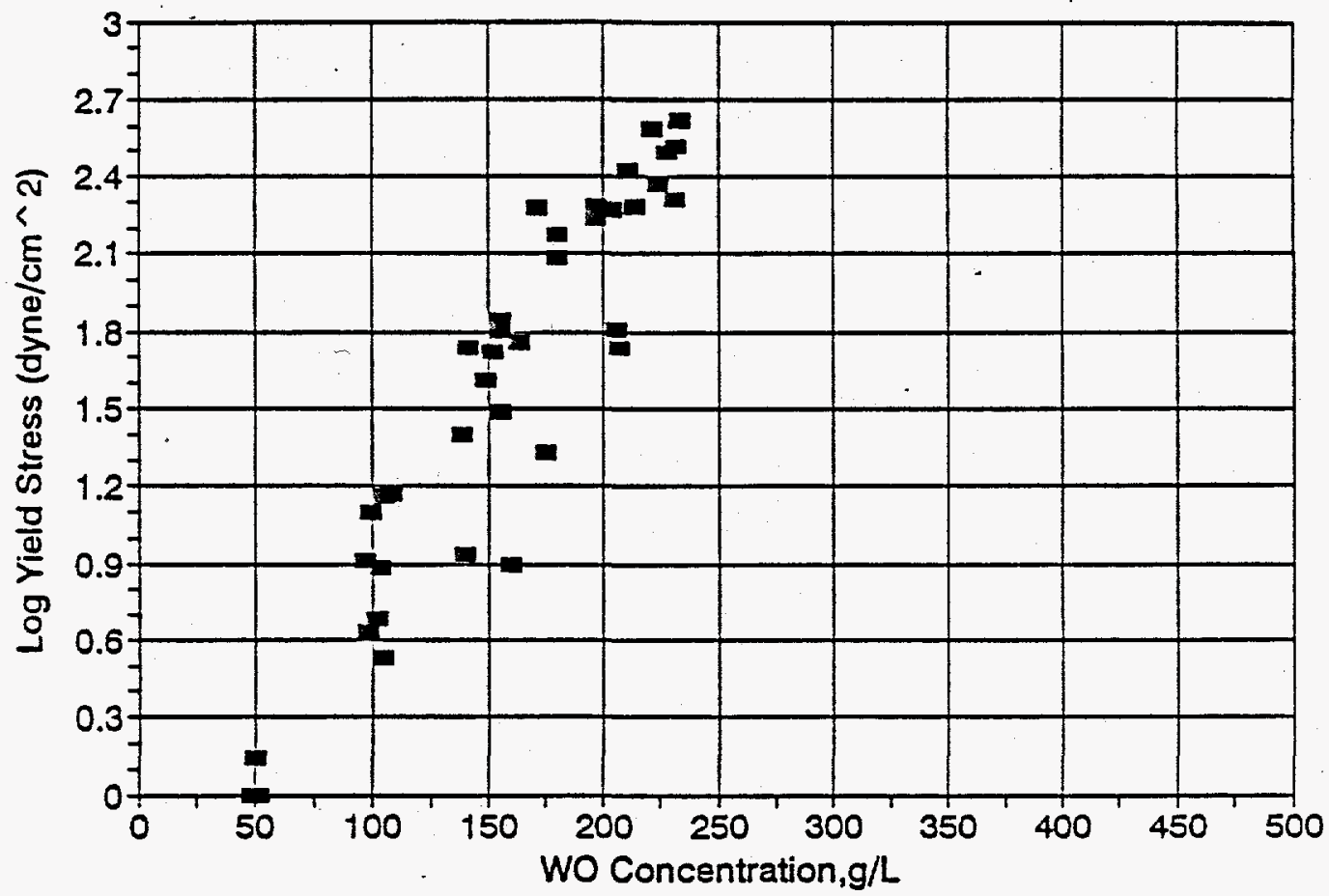

FIGURE 9. Log of NCAW Yield Stress Versus 0xide Concentration (Farnsworth et a1. 1986 Appendix B; data at $\mathrm{pH} 4$ and 6)

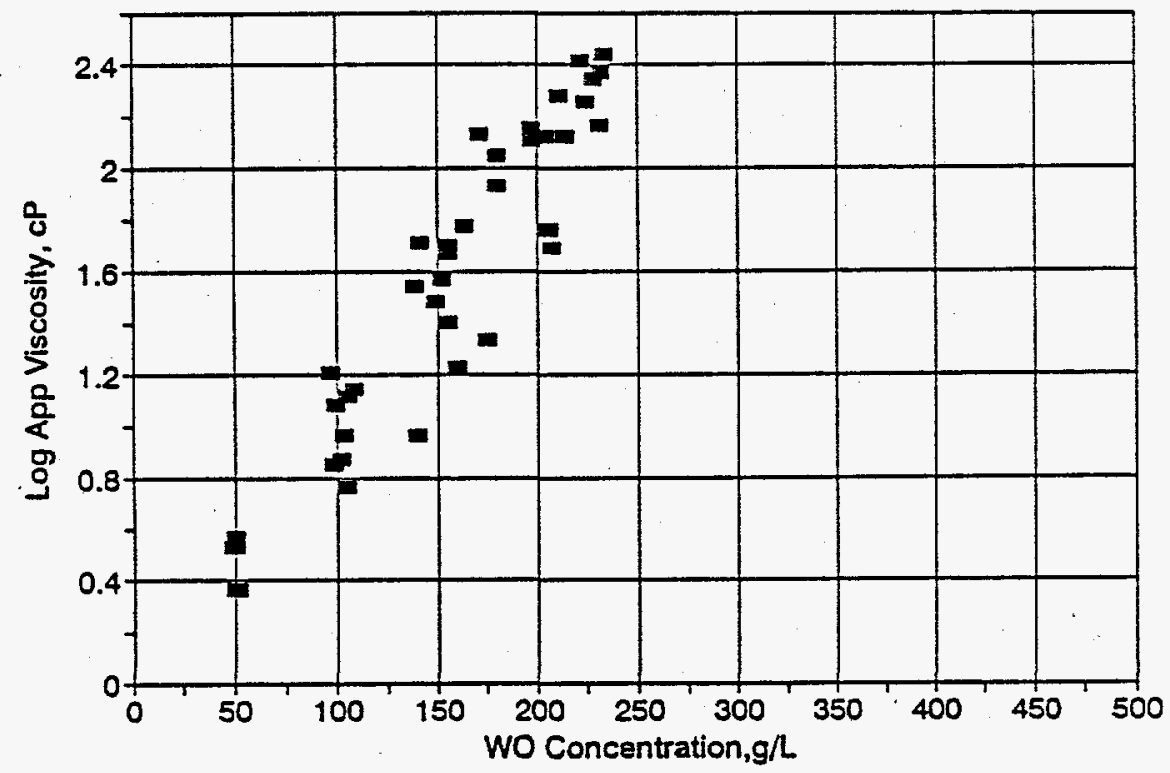

FIGURE 10. Log of NCAW Apparent Viscosity Versus 0xide Concentration

(Farnsworth et a1. 1986. Appendix B; data at shear rate of $183 \mathrm{~s}^{-1}$ and $\mathrm{pH} 4$ and 6) 


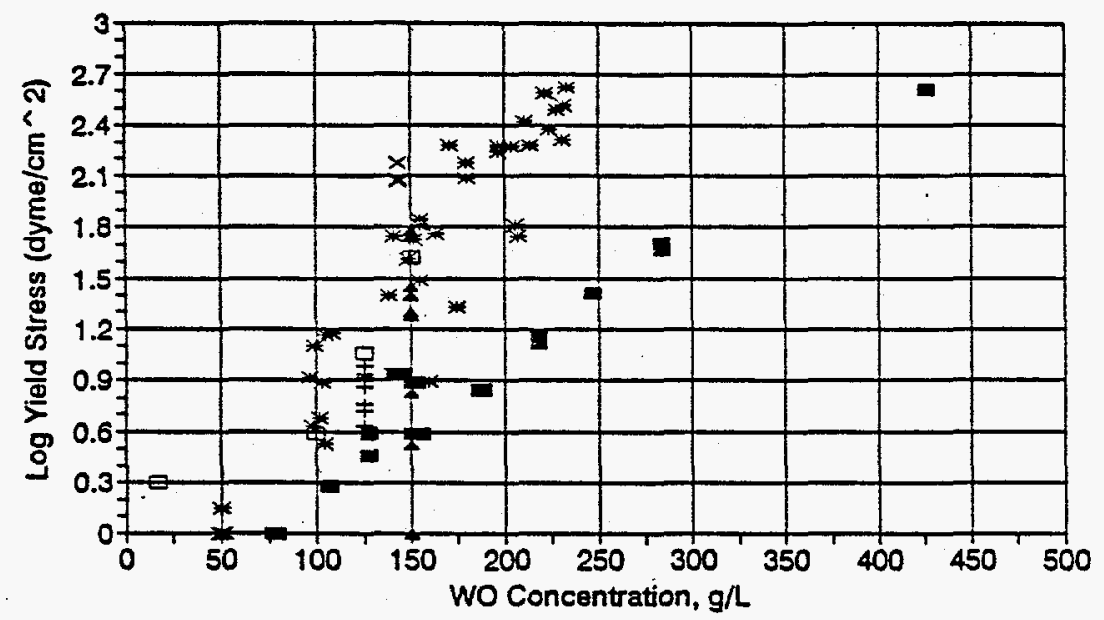

\begin{tabular}{|lllll}
\hline Thornton 1987 & + Wiemers $1990 \quad \square$ & Scheele 1985 \\
$\times$ Wiemers 1987 & \& Famsworth 1987 * Fansworth 1986
\end{tabular}

FIGURE 11. Log of NCAW Yield Stress Versus Oxide Concentration (Thornton 1987 data compared to data from Farnsworth 1986 and 1987, Scheele et

al. 1985, and Wiemers et al. 1987 and 1990; formated samples only)

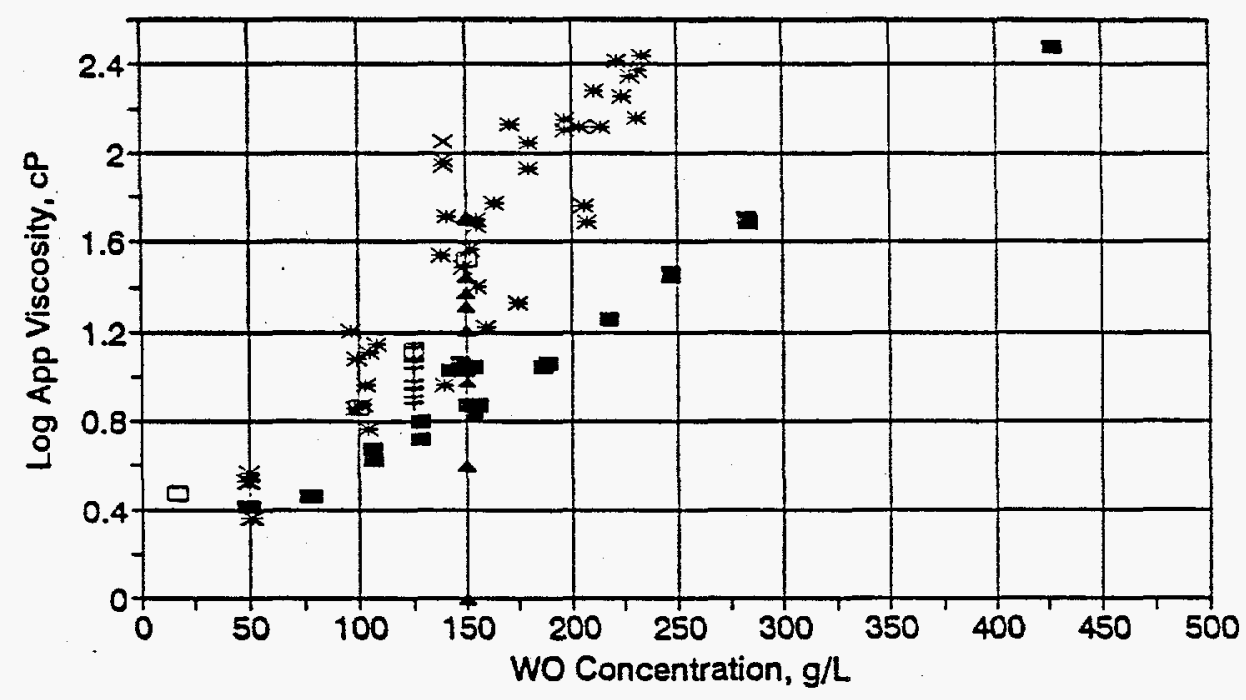

\begin{tabular}{|lllll|}
\hline Thornton 1987 & + Wiemers 1990 & $\square$ & Scheele t985 \\
$\times$ Wiemers 1987 & $\perp$ Famsworth 1987 & $*$ & Farnsworth 1986 \\
\hline
\end{tabular}

FIGURE 12. Log of NCAW Apparent Viscosity Versus 0xide Concentration at Shear Rate of $183 \mathrm{~s}^{-1}$ (Thornton 1987 data compared to data from

Farnsworth 1987, Scheele et a1. 1985, and Wiemers et al. 1987 and 1990 ; formated samples onty) 


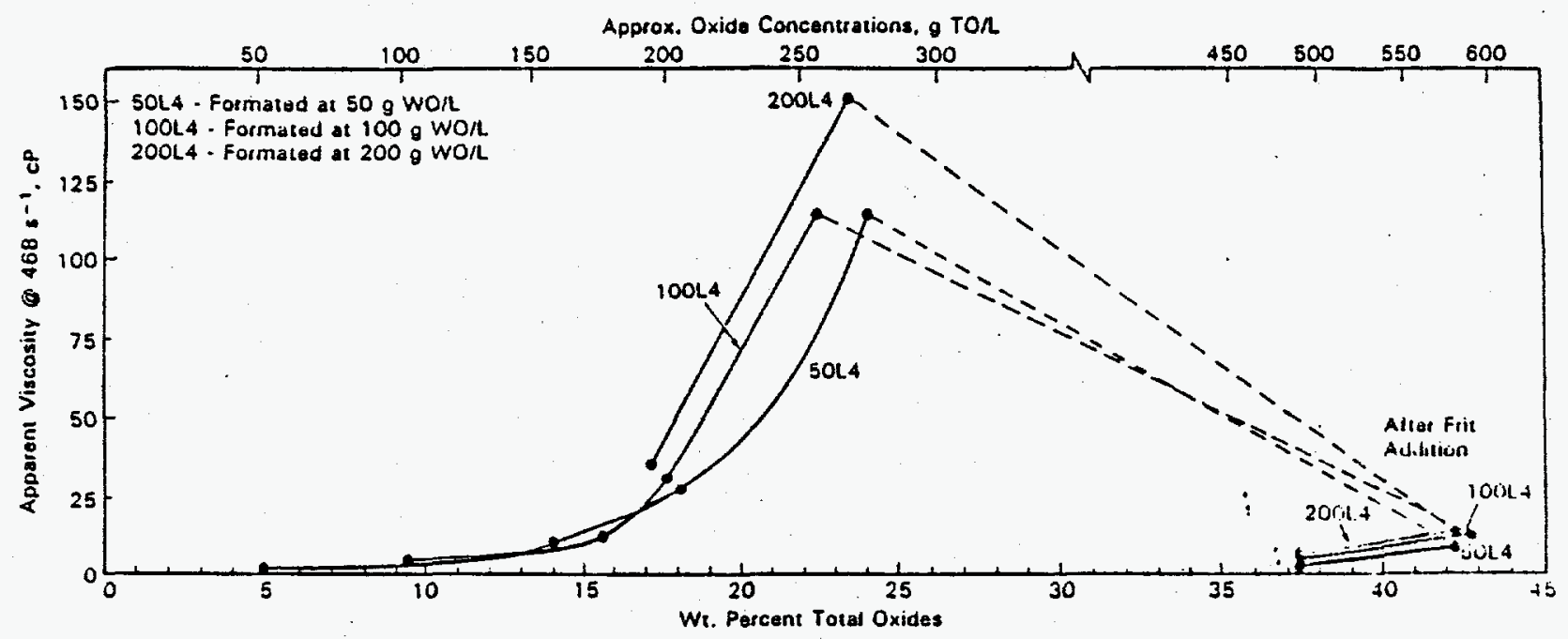

FIGURE 13. Yield Stress Versus 0xide Concentration for NCAW-to-MF Transition, Also Showing Formating Effects (Farnsworth et al. 1986)

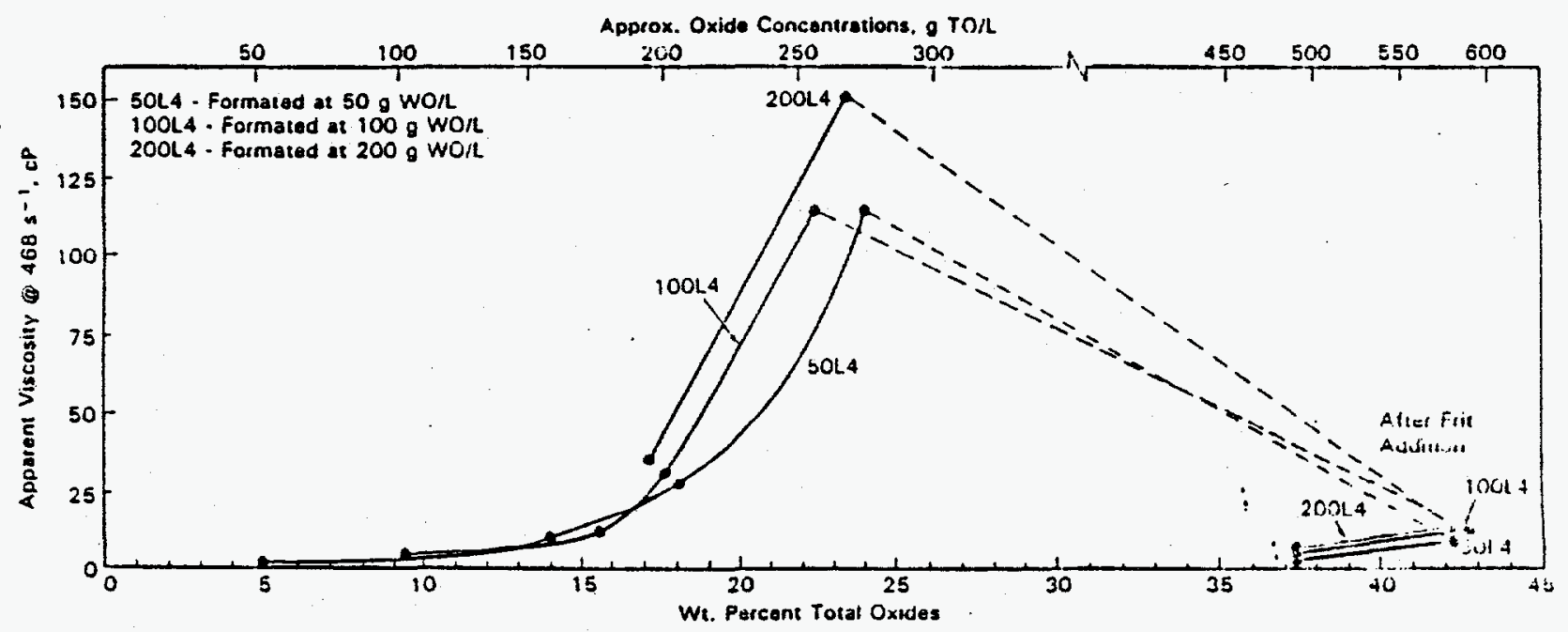

FIGURE 14. Apparent Viscosity Versus Oxide Concentration at Shear Rate of $183 \mathrm{~s}^{-1}$ for NCAW-to-MF Transition, Also Showing Formating Effects (Farnsworth et al. 1986) 


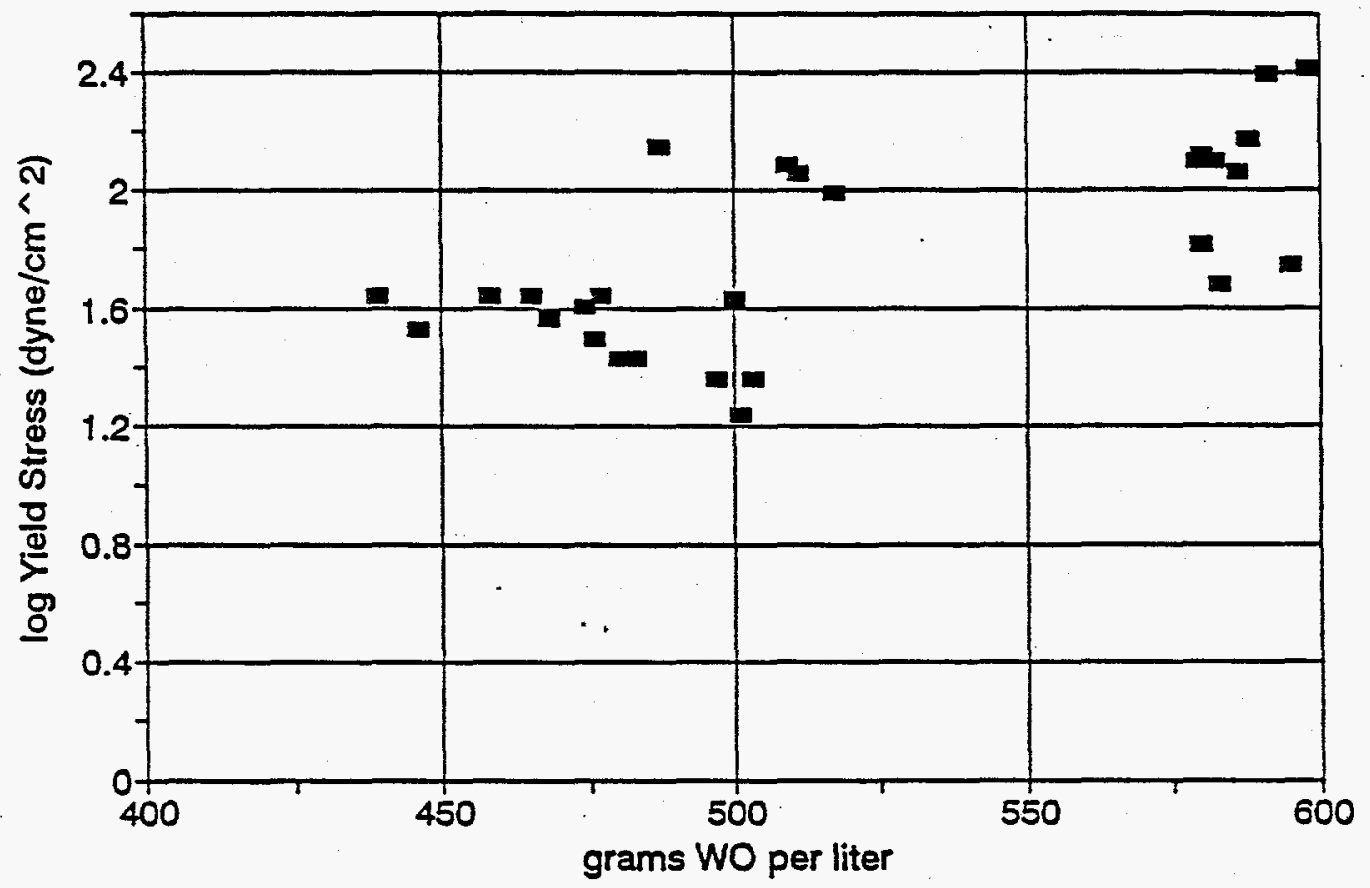

FIGURE 15. Log of Yield Stress Versus Oxide Concentration for MF S7urries (Farnsworth et a?. 1986, Appendix B; data at $\mathrm{pH} 4$ and 6)

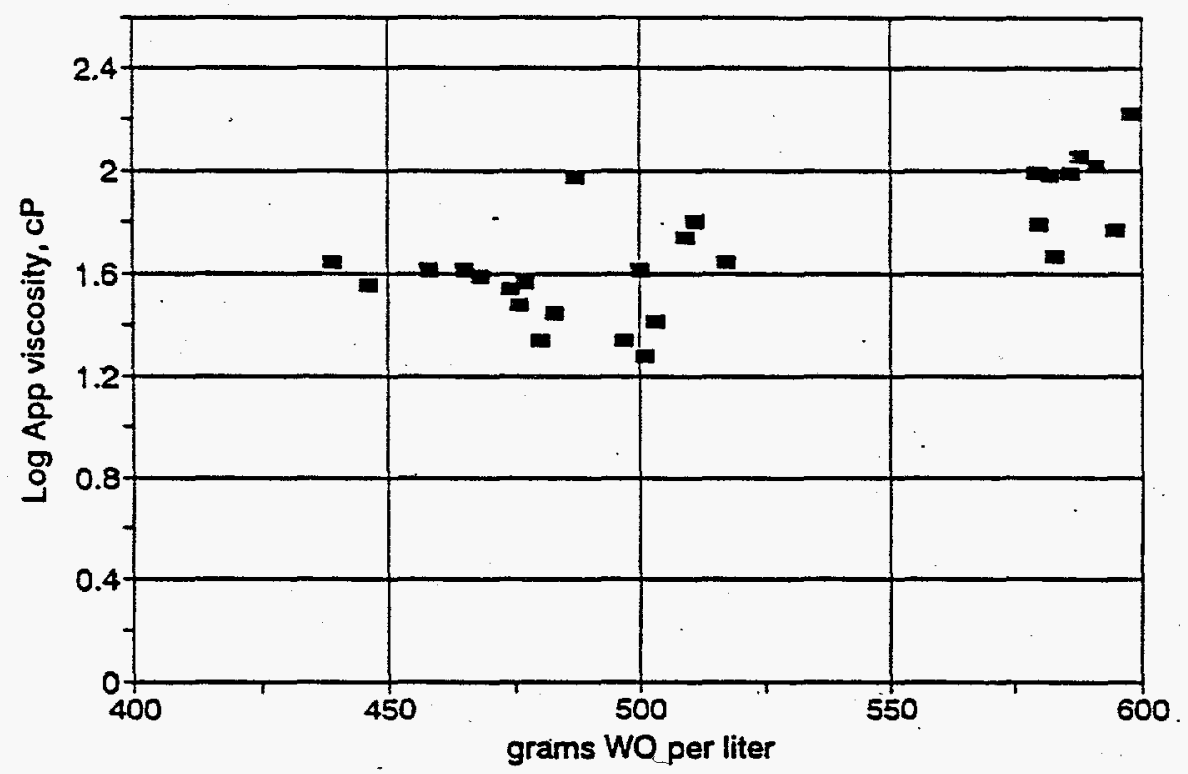

FIGURE 16. Log of Apparent Viscosity Versus 0xide Concentration at a Shear Rate of $183 \mathrm{~s}^{-1}$ for MF Slurries (Farnsworth et a). 1986, Appendix $\mathrm{B}$; data at $\mathrm{pH} 4$ and 6 ) 


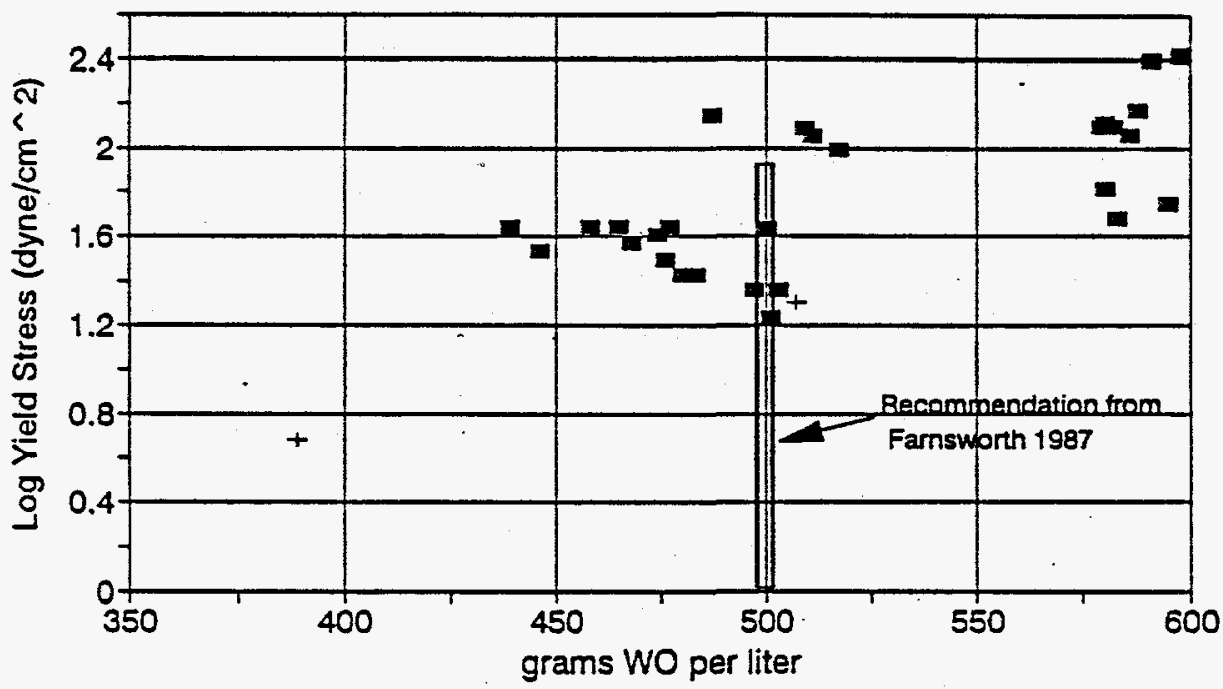

Farnsworth 1986

+ Scheele 1985

FIGURE 17. Log of Yield Stress Versus 0xide Concentration for MF Slurries (data from Farnsworth et al. 1986 compared to data from Scheele et a1. 1985 and recommended range in Farnsworth 1987)

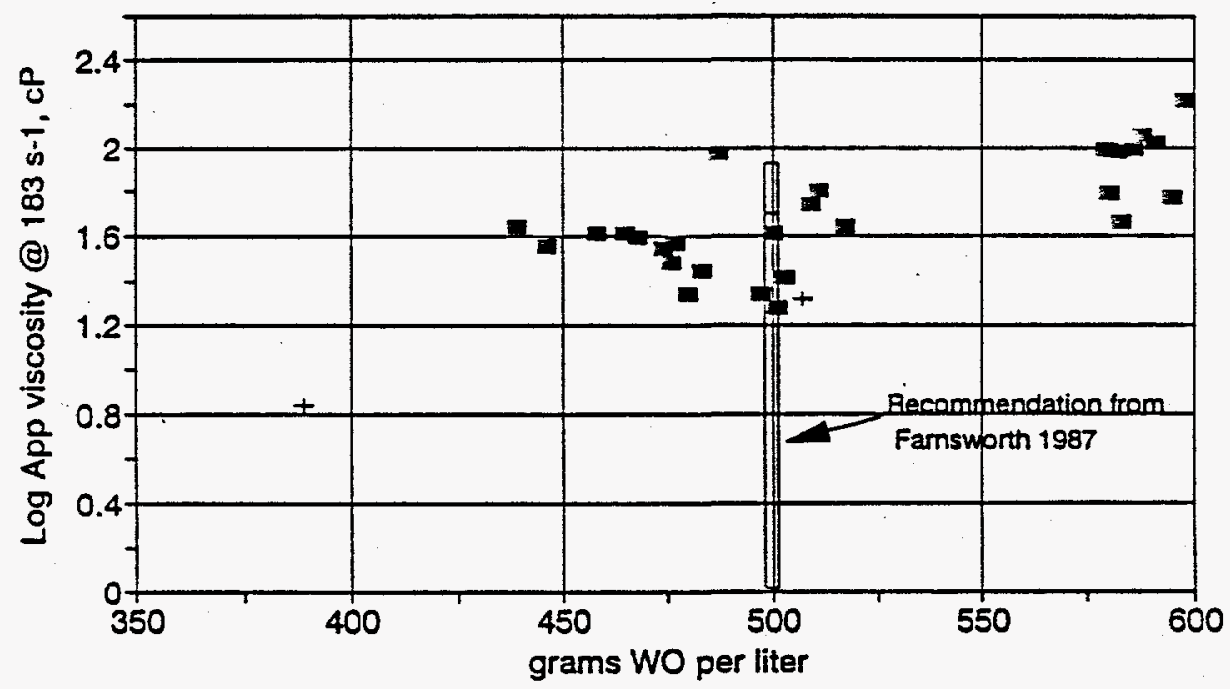

Farnsworth 1986

+ Scheele 1985

FIGURE 18. Log of Apparent Viscosity Versus 0xide Concentration for MF Slurries at a Shear Rate of $183 \mathrm{~s}^{-1}$ (data from Farnsworth et al. 1986 compared to data from Scheele et al. 1985 and recommended range from Farnsworth 1987) 
and 18, together with companion plots at the higher strain rates (Appendix A), represent the best estimates of the trends and bounds for the rheological parameters of the MFs.

\subsection{RHEOLOGICAL DATA BASE}

The current rheological data base of measurements taken from HWVP feed slurries is not comprehensive in terms of the major determinant parameters (slurry type, composition, preparation procedure, and chemistry). The data base becomes less definitive as one notes anomalies apparently connected to ferric hydroxide chemistry, particle size, or $\mathrm{pH}$, for example. These anomalies can result in discrepancies of: up to an order of magnitude in the apparent viscosities and yield stresses for a given strain rate and concentration. Furthermore, the data base also contains probable discrepancies between tested and actual HWV feed chemistries (Wiemers 1990), and between tested and actual extremes of shear strain rate and stress. For example, the variability in NCAW chemistry makes defining the simulated waste chemistry difficult.

The data base is best described as containing "bounding" statements or estimates regarding the yield stresses and viscosities of the tested materials. The rheological properties of actual NCAW and MF materials in the HWVP could be expected to be within these bounds, subject to the qualification that the tested materials and test conditions span the range of interest. Estimated upper and lower bounds for the yield stress and apparent viscosity of NCAW and MF are given in Table 6. 
TABLE 6. Estimated Upper/Lower Bounds on Rheological Parameters for NCAW and MF

$\begin{array}{lcc}\begin{array}{c}\text { HWVP } \\ \text { Material }\end{array} & \begin{array}{c}\text { Yield Stress } \\ \text { Upper/Lower } \\ \text { Bound,dyne } / \mathrm{cm}^{2}\end{array} & \begin{array}{c}\text { Viscosity } \\ \text { Upper } / \text { Lower Bound } \\ \text { e } 183 \mathrm{~s}^{-1} \mathrm{Cp}\end{array} \\ \text { NCAW, } 50 \mathrm{~g} / \mathrm{L} & 13 / 1.0 & 32 / 2 \\ \text { NCAW, } 100 \mathrm{~g} / \mathrm{L} & 39 / 2.5 & 59 / 3 \\ \text { NCAW, } 150 \mathrm{~g} / \mathrm{L} & 111 / 8 & 107 / 6 \\ \text { NCAW } 200 \mathrm{~g} / \mathrm{L} & 320 / 10 & 195 / 10 \\ \text { MF,400 g/L } & 40 / 5 & 40 / 6 \\ \text { MF, } 500 \mathrm{~g} / \mathrm{L} & 80 / 10 & 125 / 10 \\ \text { MF, } 600 \mathrm{~g} / \mathrm{L} & 250 / 40 & 250 / 40\end{array}$





\subsection{SYNOPSIS OF SOURCE-DOCUMENT CONCLUSIONS ON NCAW/MF SLURRY RHEOLOGY}

The majority of the slurry rheology data base comes from two sources: Thornton 1987 and Farnsworth et a1. 1986. The conclusions from these two sources will be summarized below, followed by summaries of the remaining sources, which offer important additional insights on slurry rheology, especially its variability.

\subsection{THORNTON 1987}

This study compared an "updated" NCAW composition (HWS9 = NCAW '86), with a previous composition (HWS7 = HWVP-RF). Attention was given to physical and rheological properties as functions of heat treating and formating. (Heat treating is analagous to what is currently called the digestion period.)

Thornton concluded that the shift in composition did not affect physical properties, and that rheological properties of HWVP-RF conservatively represent those of NCAW ' 86 . Formating to $\mathrm{pH} 4$ decreased the apparent viscosity and yield stress of the HWVP-RF more than for the NCAW' 86 slurries. Heat treating for 2 and 4 hours after formating was rheologically insignificant and resulted in small pH changes for HWVP slurries; Thornton recommended that the heat treatment step be deleted from the process.

\subsection{FARNSWORTH ET AL. 1986}

This document covers single-variable tests in the areas of formating, concentrating, and heat treating; multivariable tests related to the effects of slurry preparation; and tests on the effects of scale-up and slurry preparation.

As Thornton found, formic acid treatment decreased the yield stress and apparent viscosity, and more than the "stoichiometric" addition (the amount of formic acid required to react with all monovalent and divalent cations) of formic acid was required to obtain these effects. Also as Thornton found, heat treating had little effect on rheological or physical properties; and the NCAW slurry could be concentrated after formating to at least $190 \mathrm{~g}$ wo per 
liter before substantial increases in apparent viscosity and yield stress are incurred. Melter feed properties were similar whether the starting NCAW slurries were dilute or concentrated.

Melter feed rheology appeared somewhat improved based on decreases in apparent viscosity and yield stress when the MF was formed from NCAW with low $\mathrm{pH}$ ( $\mathrm{pH}-4$, implying $2 x$ formic acid stoichiometry). Agitation following frit addition also improved MF rheology. Two-weeks aging of the MF had little effect on the rheological properties. Farnsworth also concluded that DWPF specifications do not directly apply to HWV slurries because of differences in composition and behavior.

Scale-up did not affect the rheological properties. Ferric hydroxide chemistry dominated the rheological properties of the NCAW, but these effects were attenuated by formating, concentration, and frit addition. Melter feed preparation methods varied from a simulated actual waste processing procedure to methods combining chemicals of primarily hydroxide form ("rigorous" versus "simplified"). These variations resulted in similar trends for rheological properties. Increases in slurry particle size increased settling rates.

Farnsworth suggested that a more fundamental approach be sought for the connection between physical/chemical properties and rheological properties of the siurries, and that irradiation effects on slurry properties also be evaluated.

\subsection{FARNSWORTH 1987}

This document presents the results of studies conducted on nine variations of NCAW composition, in which rheological properties were measured at the same concentration (approximately $150 \mathrm{~g}$ W0 per liter); certain MF properties were also measured. The major conclusion is that a similar addition of formic acid (25 to $30 \mathrm{~mL}$ of formic acid/L of feed) will control both the redox state and MF rheology over the composition ranges tested. Of the composition variations studied, the variation in iron concentration had the greatest effect on MF rheology. Farnsworth recommended that carbonates, nitrites, and 
manganese oxide be added to the NCAW to make more representative simulated waste, and that no chemical modifiers other than formic acid are probably needed for HWVP NCAW.

\subsection{SCHEELE ET AL. 1985}

This document discusses the rheological properties that were measured on one NCAW composition and on two MF compositions, at oxide concentrations of 17 to $150 \mathrm{~g} / \mathrm{L}$ and 400 to $500 \mathrm{~g} / \mathrm{L}$, respectively. Scheele et al. concluded that formating reduced apparent viscosity and yield stress, and that limited temperature variations $\left(25^{\circ}\right.$ to $\left.95^{\circ} \mathrm{C}\right)$ did not lead to consistent changes in the rheological properties.

\subsection{WIEMERS 1990}

This document is a report of the chemical (redox) effects of adding nitrate and carbonate to the NCAW. The NCAW slurries were formated and concentrated to a concentration of $125 \mathrm{~g}$ WO per Titer. Rheological properties were measured as an adjunct activity. The measured values for yield stress and viscosity were consistent with those of the previous studies (see Figures 1 and 2). Formating slightly decreased the apparent viscosity and yield stress. The carbonate/nitrate additions could not be correlated with these rheological properties.

\subsection{WIEMERS ET AL. 1987}

This report focuses on the off gasing of NCAW during formating. The concentration of the tested slurries was $144 \mathrm{~g}$ wo per liter. Rheological properties were measured as an adjunct activity, and the results were remarkably higher at this concentration than at those found in other investigations (see Figures 1 and 2). However, note that these results, although high, are not beyond the 2-sigma bounds on the current total data base (see Figures 3 and 4). 


\subsection{REFERENCES}

Farnsworth, R. K., C. M. Ruecker, J. M. Perez, H. T. Blair, and G. T. Thornton. 1986. HWVP Feed Process Variability Testing for Fiscal Year 1986. HWVP-V1123C (RHO-RE-CR-16P). Rockwell Hanford Operations, Richl and, Washington. 


\subsection{CITED LETTER REPORTS (not publicly available)}

Farnsworth, R. K. 1987. The Effect of Feed Composition and Formic Acid Addition on GTaSS REDOX State. HWVP-87-V110203A, Letter Report prepared by Pacific Northwest Laboratory for Westinghouse Hanford Company, Richland, Washington.

Hamm, B. A. 1984. Memo to M. A. Ebra from B. A. Hamm. High-Level Caves Rheological Studies of Tanks 15H, 42H, 8F Sludge/Slurries. DPST-84-439, Savannah River Laboratory, Aiken, South Carolina.

Scheele, R. D., H. T. Blair, A. W. Lautensleger, and G. T. Thornton. 1985. Characterization of Simulated Hanford Waste Vitrification Program Feed and Concentrates. Letter Report prepared by Pacific Northwest Laboratory for Westinghouse Hanford Company, Richland, Washington.

Thornton, G. T. 1987. Evaluation and Comparison of HWVP-Reference Feed Composition and Updated Neutralized Current Acid Waste Composition Simulants. HWVP-87-V110203C, Letter Report prepared by Pacific Northwest Laboratory for Rockwell Hanford Operations, Richland, Washington.

Wiemers, K. D., C. A. Anderson, and M. E. Peterson. 1987. Evaluation of Process off Gases Released During the Formating of an HWVP Simulant. HWVP-87-V1102030G, Letter Report prepared by Pacific Northwest Laboratory for Westinghouse Hanford Company, Richland, Washington.

Wiemers, K. D. 1990. The Effect of HWVP Feed Nitrate and Carbonate Content on Glass REDOX Adjustment. HVWP-90-1.2.2.03.03A, Letter Report prepared by Paicifc Northwest Laboratory for Westinghouse Hanford Company, Richland, Washington. 



\subsection{ANNOTATED BIBLIOGRAPHY}

\section{Pacific Northwest Laboratory Documents}

1. Memo to L. C. Stegen from HWVP Systems Engineering. HWVP Feed Tank Agitation Assessment. Internal memo 85433-91-067.

Rheology data were not included. Agitation was assessed.

2. Harvey, C. D., and H. T. Blair. 1984. Improving the Rheology of Melter Feed Made with Hanford Wastes. Prepared by Pacific Northwest Laboratory, Richland, Washington.

The Brookfield viscometer was used to obtain average viscosity. No yield stress information was provided. In one instance, two points were used to fit a curve.

3. Perez, J. M., H. T. Blair, R. W. Goles, and W. C. Buckmilier. 1984. Effect of Rheological Control Agents on Glass Melting Process. 7H35-84-21, prepared by Pacific Northwest Laboratory, Richland, Washington.

Sucrose solutions analogues were used to measure viscosity. These data should not be used in this task because sugar and waste have functionally different rheological behavior.

4. Nakaoka, R. K., and S. O. Bates. 1985. HWVP High Bay Ceramic Melter Run Summary. HWVP11/HBCM-85-1, prepared by Pacific Northwest Laboratory, Richland, Washington.

Rheology was an afterthought in this experimentation. Some yield stress information was included. Rheological information was composed of shear rates 183,608 , and $824 \mathrm{~s}^{-1}$. The rheograms were not included.

5. Wiemers, K. D., C. A. Anderson, and M. E. Peterson. 1987. Evaluation of Process Off Gases Released During Formating of an HWVP Feed Simulant. HWVP-87-V1102030G, Letter Report prepared by Pacific Northwest Laboratory for Westinghouse Hanford Company, Richland, Washington.

Rheology was not the focus of this investigation. Rheograms were not included. Rheological information was composed of shear rates 183, 323, and $468 \mathrm{~s}^{-1}$.

6. Wiemers, K. D. 1990. The Effect of HWVP Feed Nitrate and Carbonate Content on Glass Redox Adjustment. HWVP-90-1.2.2.03.03A, Letter Report prepared by Pacific Northwest Laboratory for Westinghouse Hanford Company, Richland, Washington.

This was not a rheology study. Rheology was measured as a function of feed chemistry. 
7. Farnsworth, R. K. 1987. The Effect of Feed Composition and Formic Acid on Glass Redox State. HWVP-87-V110203A, Letter Report prepared by Pacific Northwest Laboratory for Westinghouse Hanford Company, Richland, Washington.

The yield stress versus $\mathrm{pH}$ and formic acid addition was compared: This report contains some good rheology data.

8. Farnsworth, R. K., C. M. Ruecker, J. M. Perez, H. T. Blair, and G. T. Thornton. 1986. HWVP Feed Process Variability Testing for Fiscal Year 1986. HWVP-V1123C (RHO-RE-CR-16P). Rockwell hanford Operations, Richland, Washington.

Credible rheological data are contained.

9. Thornton, G. T. 1987. Evaluation and Comparison of HWVP-Reference Feed Composition and Updated Neutralized Current Acid Waste Composition SimuIants. HWVP-87-V110203C, Letter Report prepared by Pacific Northwest Laboratory for Rockwell Hanford Operations, Richland, Washington.

Credible rheological data are contained.

10. Scheele, R. D., H. T. Blair, A. W. Lautensleger, and G. T. Thornton. 1985. Characterization of the Simulated Hanford Waste Vitrification Program Feed and Concentrates. Letter Report prepared by Pacific Northwest Laboratory for Westinghouse Hanford Company, Richland, Washington.

Credible rheological data is contained.

11. Heath, W. 0. March 1986. Development of Tank Sludge Simulants and Further Development of Shear Vane Sludge Test Methods. Prepared by Pacific Northwest Laboratory, Richland, Washington.

Silica-based simulants were developed. Particle size of the developed simulant was 22 nanometers. The simulants were used to measure yield stress with the shear vane. These data cannot be used coherently in this project.

Savannah River Laboratory Documents

12. Memo to C. T. Randall from T. T. Trinh, November 7, 1988 . Determination of DWPF Process Stream Yield Stress and Consistency Using Capillary Viscometer Technique. DPST-87-803-TL, Savannah River Laboratory, Aiken; South Carolina.

Used fritted sludge samples at two solids concentrations ( 40 wt\% and $50 \mathrm{wt} \%$ ). Measured yield stress and consistency. Composition is not clearly documented. Applicability to the HWVP task is questionable. 
13. Memo to M. A. Ebra from B. A. Hamm. Apri1 11, 1984. High Level Caves Rheological Studies of Tanks $15 \mathrm{H}, 42 \mathrm{H}$, and $8 \mathrm{~F}$ Sludge STurries. DPST-84-439, Savannah River Laboratory, Aiken, South Carolina.

The $15 \mathrm{H}, 42 \mathrm{H}$, and $8 \mathrm{~F}$ tanks were sampled. The yield stress and viscosity were measured. The reported data are quite scattered. It is unclear how the data apply to our task.

14. Memo to D. C. Witt from R. K. Steidlitz. and D. M. Grimm, August 21, 1984. DWPF Melter Feed System Testing. DPST-84-649, Savannah River Laboratory, Aiken, South Carolina.

The data included pressure drops and pump speed versus melter flow. This is not a rheological study.

15. Memo to C. T. Randall from J. A. Voogd, July 30, 1987. Pump and Agitation in the CPC-Capacity and Attainment DPST-87-574TL, Savannah River Laboratory, Aiken, South Carolina.

Pumping and agitation were examined. Rheology was not examined.

16. Memo to M. A. Ebra from J. M. Fazio, February 6, 1987. Results of Sludge Slurry Pipeline Pluggage Tests. DPST-87-271, Savannah River Laboratory., Aiken, South Carolina.

Pipeline pressure gradients versus flow was compared. One unreliable rheogram (based on several spurious spikes on the curve) was included. This information cannot be applied to the task.

17. Memo to F. H. Brown from D. P. Lewis, March 18, 1982. DWPF S7urry Pump Requirements. DPST-82-406, Savannah River Laboratory, .Aiken, South Carolina.

The report concluded: "Good slurry pump design requires careful consideration of all parameters," including slurry rheology. Rheology data were not included.

18. Memo to J. K. Okeson from C. T. Randa11, October 31, 1980. Pumping Requirements for Sludge Transfers Through the Interarea Transfer Lines. DPST-80-468-TL, Savannah River Laboratory, Aiken, South Carolina.

This report was highly specific. Sludge water/slurry mixtures were examined for pumping applications. Examined tank transfer requirements. Rheology data were not included.

19. Memo to R. B. Ferguson from J. R. Fowler, June 29, 1982. Rheology of Synthetic Feed for the Slurry Fed Melter. DPST-81-491, Savannah River Laboratory, Aiken, South Carolina. 
The rheological principles that apply to the waste were described. Rheology data were taken for two concentration schemes. The compared schemes were centrifugation and evaporation. A limited amount of data was given in the form of yield stress versus frit particle size.

20. Memo to M. D. Boersma from D. W. Jones, November 12, 1979. DWPF Liquid Feed Data for TNX Glass Melter. DPST-79-565, Savannah River Laboratory, Aiken, South Carolina.

Consistency and yield stress were measured as functions of solids loading. Composition was not disclosed.

21. Memo to J. K. Okeson from T. Motyke, November 25, 1980. Yield Stress Determinations from a Relative Viscometer. DPST-80-688, Savannah River Laboratory, Aiken, South Carolina.

Kaol in slurries were examined. The rheology of the kaol in was related to the sludge by analogy. The sludge composition was not given. This type of experimentation is unadvisable and irrelevant. Functionally, the rheology of kaolin suspension and sludge is different.

22. Memo to F. H. Brown from D. P. Lewis, July 12, 1982. Georgia Iron Works Testing Program Update. DPST-82-694-TL, Savannah River Laboratory, Aiken, South Carolina.

Sludge yield stresses were measured by the Brookfield viscometer. The use of this device is only advisable to extract "average viscosity."

23. Memo to J. F. Ortaldo from T. Motyka, March 16, 1981. Estimating Floc Size and Concentration of Waste Slurries for Use in Determining Transport Conditions for Interarea Transfers. DPST-81-324, Savannah River Laboratory, Aiken, South Carolina.

Settling velocities and floc size were studied. Rheology was not examined.

24. Memo to C. T. Randall from I. D. Green, June 5, 1985 . In Line Viscometer Testing Results. DPST-85-325, Savannah River Laboratory, Aiken, South Carolina.

The report concluded that an inline viscometer may provide faster and convenient determination of consistency. Rheology data were not provided.

25. Memo to F. H. Brown from D. P. Lewis. Sludge Slurry Hydraulic Data. DPST-82-954-TL, Savaninah River Laboratory, Aiken, South Carolina.

Two rheograms were provided. One of the rheograms showed obvious anomalies and is unusable. 
26. Hamm, B. A., W. L. West, and G. B. Tatterson. 1991. Sludge Suspension in Waste Storage Tanks. DP-MS-89-61, Savannah River Laboratory, Aiken, South Carolina.

Rheology data were not provided. Homogeneity issues within the tanks were addressed.

27. Memo to C. T. Randall from T. T. Trinh, November 7, 1988. Feeding Formic Acid onto the Liquid Surface. DPST-88-607, Savannah River Laboratory, Aiken, South Carolina.

Rheology data were not provided. Formic acid additions were investigated.

28. Memo to File from D. P. Lewis, December 31, 1982. Combination Document, Flow Characteristics of Simulated Slurries. Prepared by Georgia Iron Works Hydraulic Test Laboratory. DPST-82-955, Savannah River Laboratory, Aiken, South Carolina.

Pipeline performance was studied. It was concluded that the slurries behave as a Bingham plastic. No settling problems were observed. Two rheology tests were conducted. The suspensions were clay based. Pressure drops were measured. The authors wrote, "Rheograms are superfluous except for comparison of rheologic characteristics using other types of viscometers." 


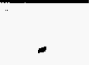




\section{APPENDIX A}

EFFECT OF STRAIN RATE ON VISCOSITY OF NCAW AND MF SLURRIES 


\section{EFFECT OF STRAIN RATE ON VISCOSITY OF NCAW AND MF SLURRIES}

The effect of shear strain rate on viscosity was shown in Figure 6 for the data from Thornton (1987). For completeness, the corresponding effects are shown here for the data from Farnsworth et al. (1986) for both NCAW and MF slurries. The effect is secondary to that of concentration in al1 three cases. This same pattern is repeated in the data of Scheele et al. 1985, and Wiemers et a]. 1987, and 1990 (not shown).

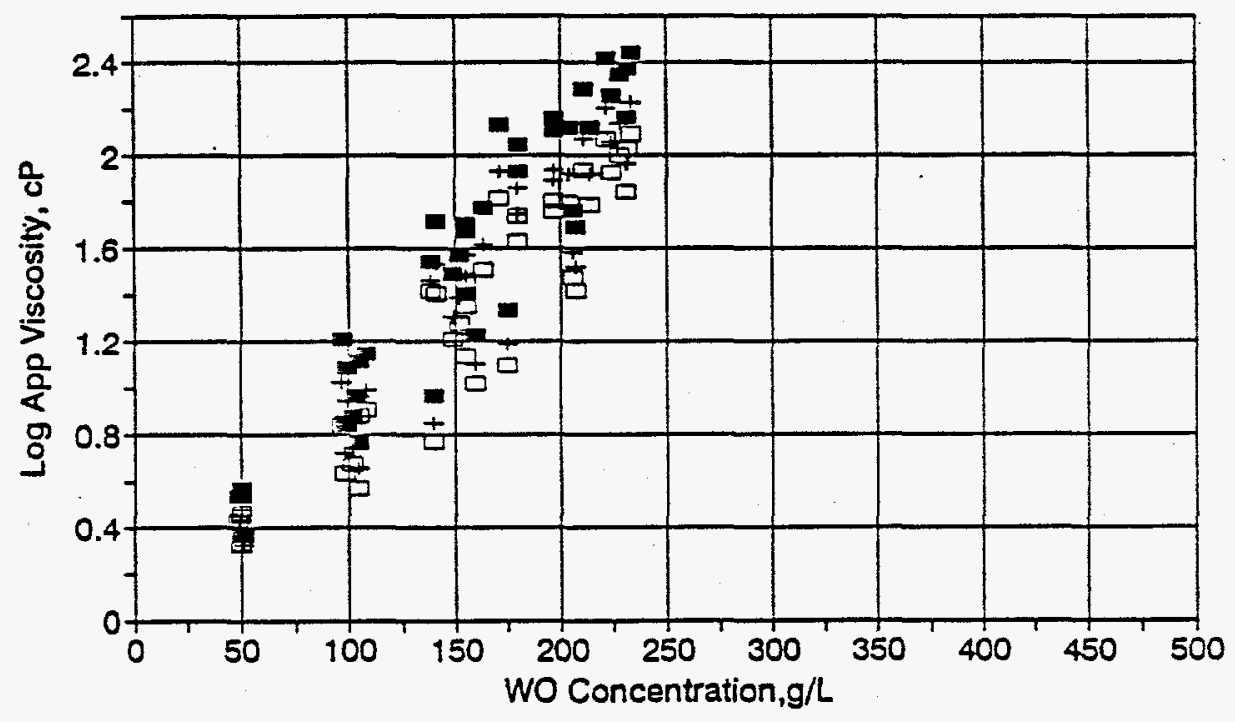

- $183 \mathrm{~s}-1+323 \mathrm{~s}-1$ 口 $468 \mathrm{~s}-1$

FIGURE A.1. Log of NCAW Apparent Viscosity Versus Oxide Concentration at Three Shear Rates (from Farnsworth et al. 1986 Appendix B; data for $\mathrm{pH} 4$ and 6) 


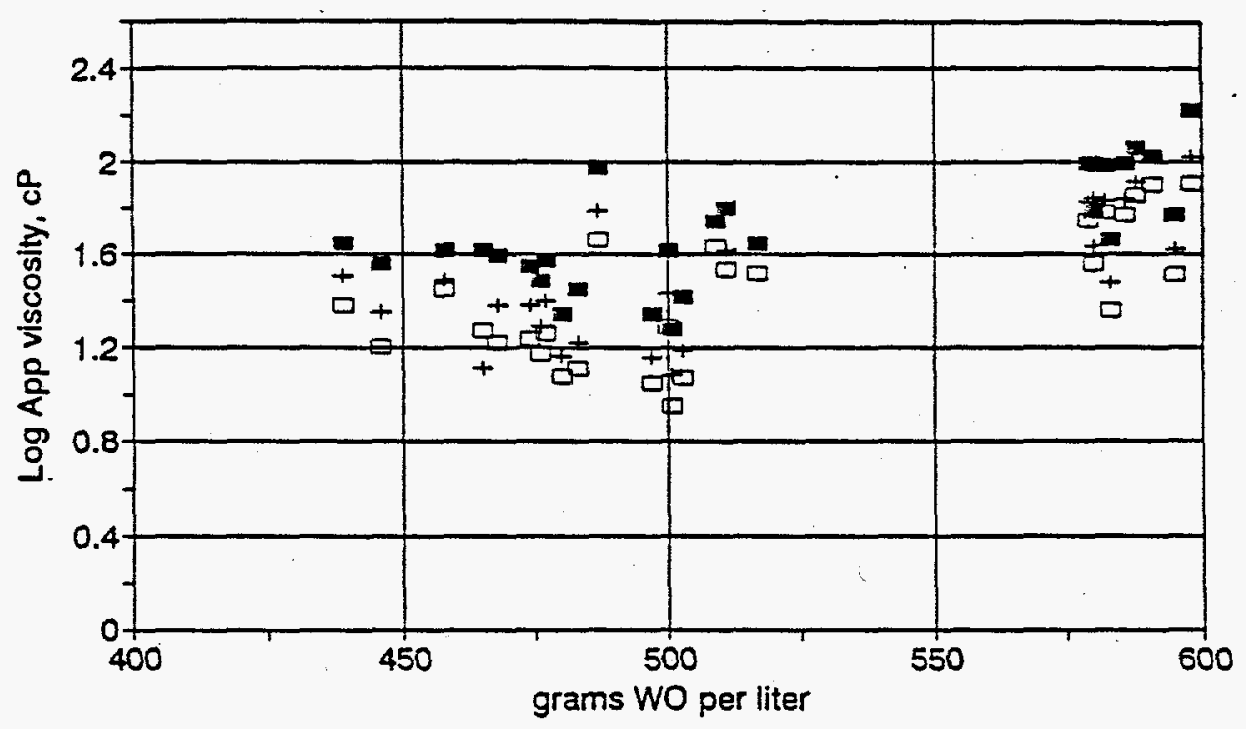

$=183 \mathrm{~s}-1+323 \mathrm{~s}-1 \square 468 \mathrm{~s}-1$

FIGURE A.2. Log of MF Apparent Viscosity Versus Oxide Concentration at Three Shear Rates (from Farnsworth et a1. 1986 Appendix B; data for $\mathrm{pH}$ 4 and 6) 


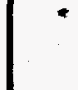

I.

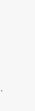




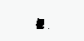

